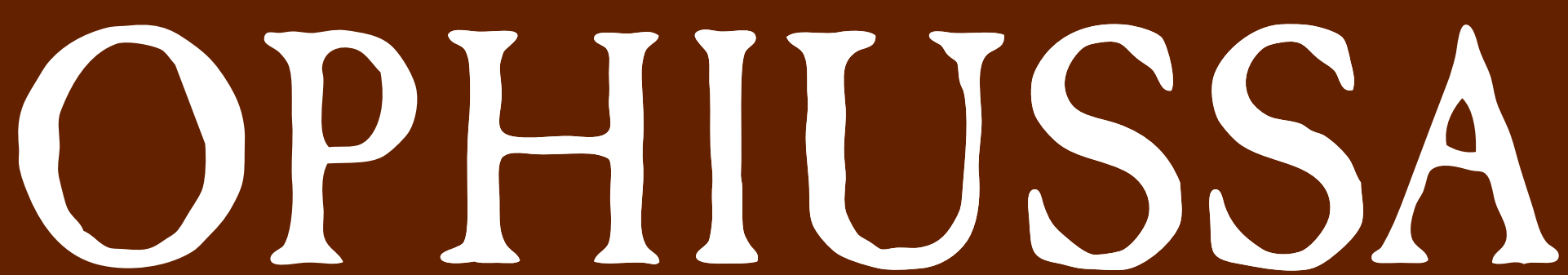
REVISTA DO CENTRO DE ARQUEOLOGIA DA UNIVERSIDADE DE LISBOA

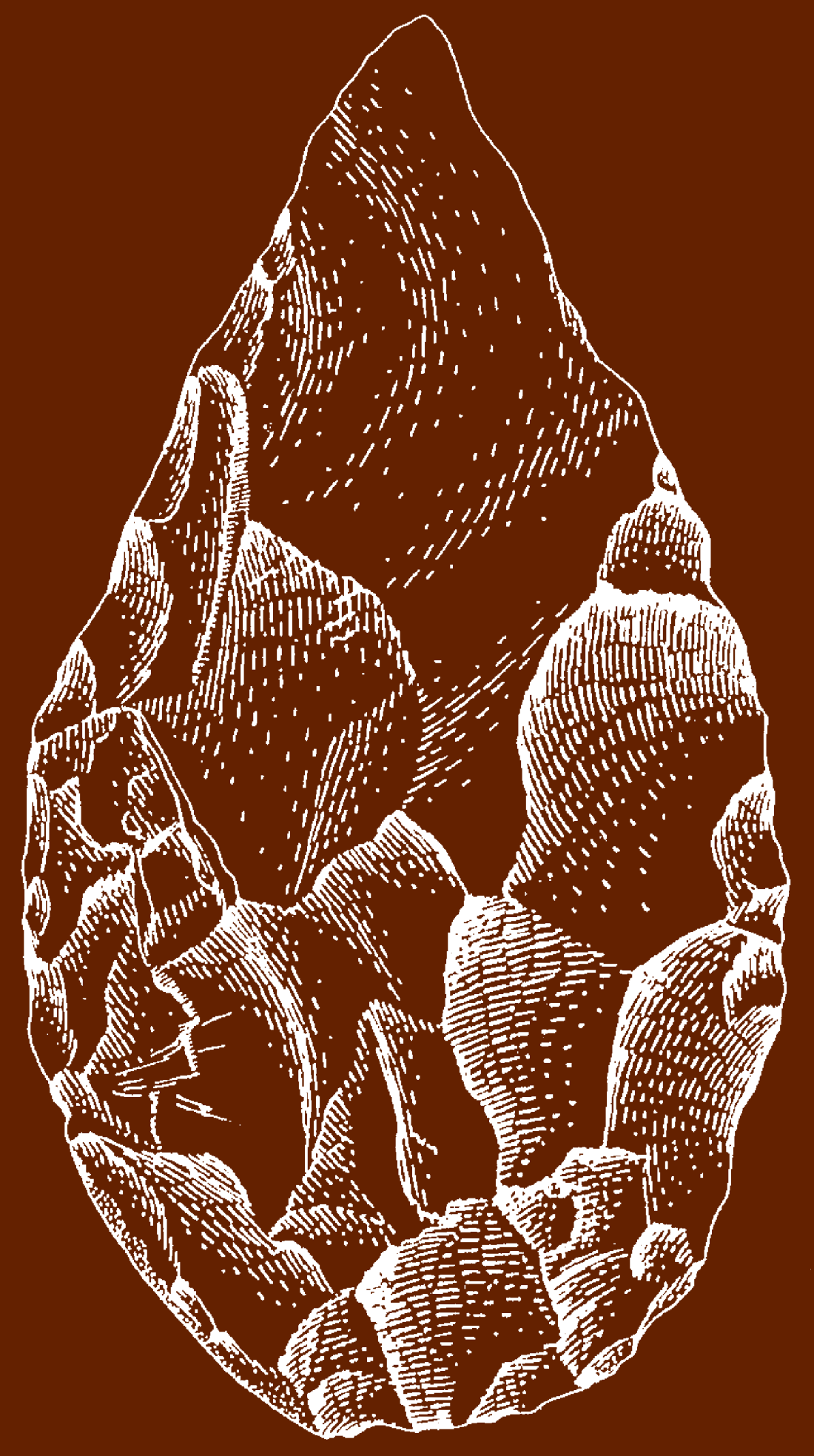

CENTRO DE ARQUEOLOGIA

DA UNIVERSIDADE

DE LISBOA 


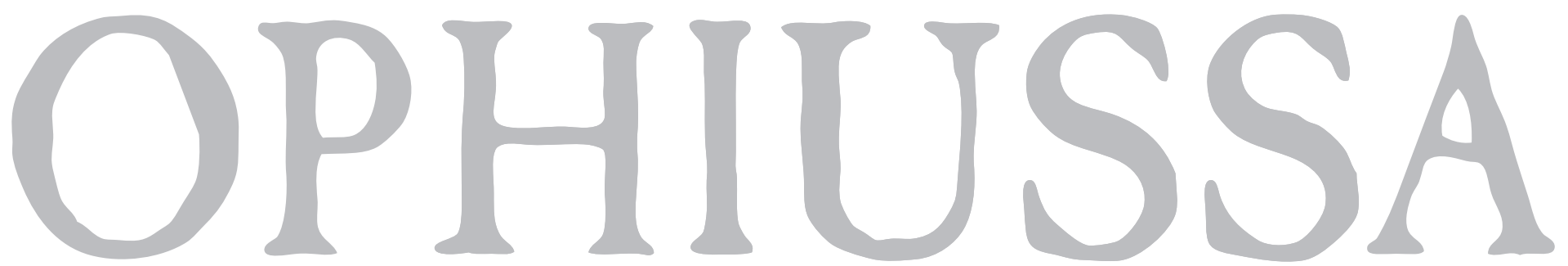

REVISTA DO CENTRO DE ARQUEOLOGIA DA UNIVERSIDADE DE LISBOA

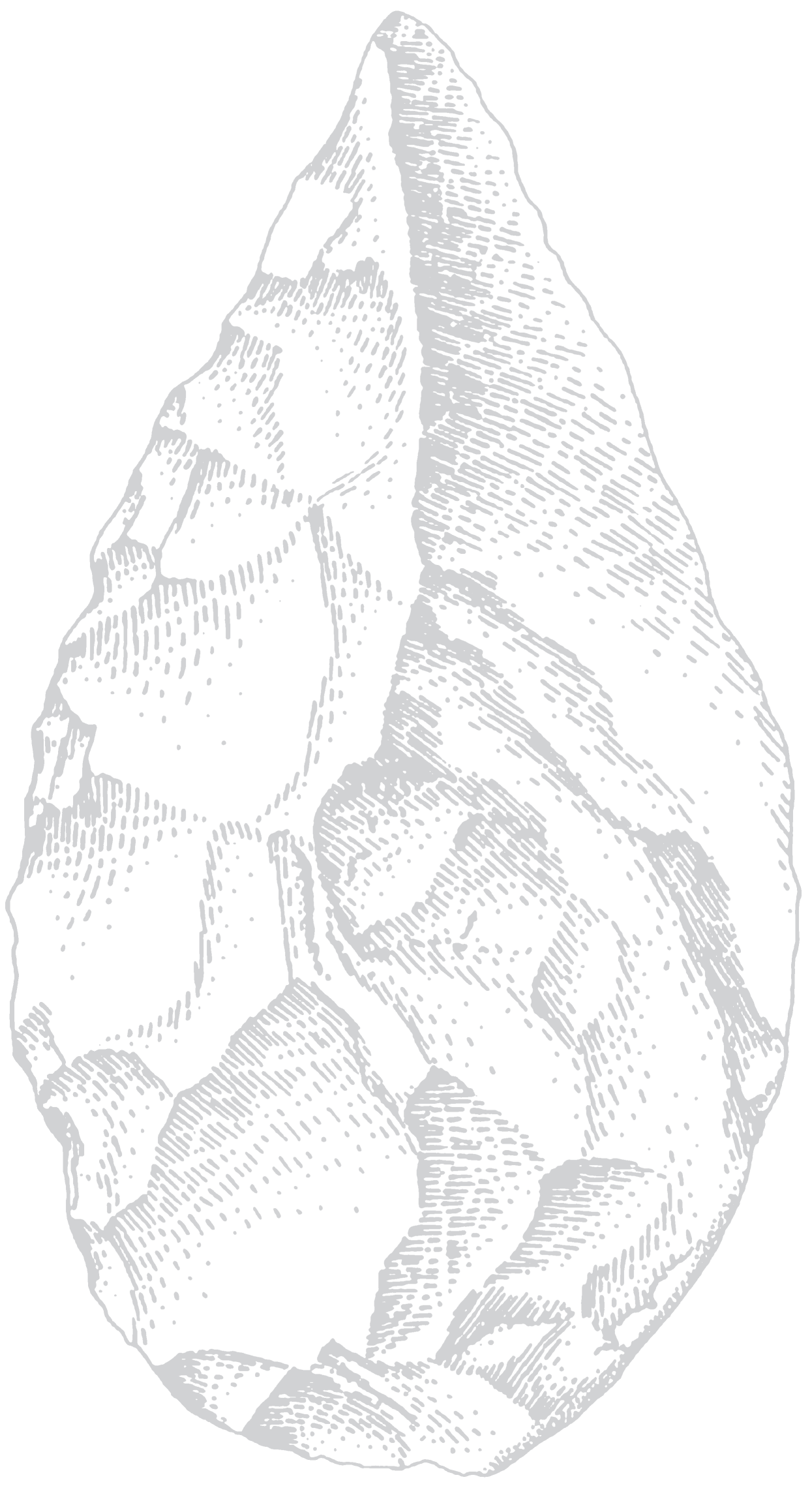




\section{U IISBOA \\ UNIVERSIDADE

\section{OPHIUSSA REVISTA DO CENTRO DE ARQUEOLOGIA DA UNIVERSIDADE DE LISBOA}

PUBLICAÇÃO ANUAL · ISSN 1645-653X · E-ISSN 2184-173X

Volume 5 - 2021

DIRECÇÃO E COORDENAÇÃO EDITORIAL

Ana Catarina Sousa

Elisa Sousa

\section{CONSELHO CIENTÍFICO}

André Teixeira

UNIVERSIDADE NOVA DE LISBOA

\section{Carlos Fabião}

UNIVERSIDADE DE LISBOA

Catarina Viegas

UNIVERSIDADE DE LISBOA

\section{Gloria Mora}

UNIVERSIDAD AUTÓNOMA DE MADRID

\section{Grégor Marchand}

CENTRE NATIONAL DE LA RECHERCHE SCIENTIFIQUE

\section{João Pedro Bernardes}

UNIVERSIDADE DO ALGARVE

José Remesal

UNIVERSIDADE DE BARCELONA

Leonor Rocha

UNIVERSIDADE DE ÉVORA

Manuela Martins

UNIVERSIDADE DO MINHO

Maria Barroso Gonçalves

INSTITUTO SUPERIOR DE CIÊNCIAS DO TRABALHO E DA EMPRESA

\section{Mariana Diniz}

UNIVERSIDADE DE LISBOA

Raquel Vilaça

UNIVERSIDADE DE COIMBRA

Victor S. Gonçalves

UNIVERSIDADE DE LISBOA

Xavier Terradas Battle

CONSEJO SUPERIOR DE INVESTIGACIONES CIENTÍFICAS

\section{SECRETARIADO}

André Pereira

\section{CAPA}

Biface proveniente de Casal do Azemél (Leiria).

Desenho de Amélia Marques. Museu D. Diogo de Sousa

(MDDS). (Cunha-Ribeiro, 1999)
REVISOR DE ESTILO

Francisco B. Gomes

PAGINAÇÃO

TVM Designers

IMPRESSÃO

AGIR - Produções Gráficas

DATA DE IMPRESSÃO

Dezembro de 2021

EDIÇÃO IMPRESSA (PRETO E BRANCO)

300 exemplares

EDIÇÃO DIGITAL (A CORES)

www.ophiussa.letras.ulisboa.pt

ISSN 1645-653X / E-ISSN 2184-173X

DEPÓSITO LEGAL 190404/03

Copyright ( $) 2021$, os autores

EDIÇÃO

UNIARQ - Centro de Arqueologia

da Universidade de Lisboa,

Faculdade de Letras de Lisboa

1600-214 Lisboa.

www.uniarq.net

www.ophiussa.letras.ulisboa.pt

uniarq@letras.ulisboa.pt

Revista fundada por Victor S. Gonçalves (1996). O cumprimento do acordo ortográfico de 1990 foi opção de cada autor.

Esta publicação é financiada por fundos nacionais através da FCT - Fundação para a Ciência e a Tecnologia, I.P., no âmbito dos projectos UIDB/00698/2020 e UIDP/00698/2020. 
ÍNDICE

O tecno-complexo Acheulense em Portugal:

contribuição para um balanço dos conhecimentos

CARLOS FERREIRA, JOÃO PEDRO CUNHA-RIBEIRO, EDUARDO MÉNDEZ-QUINTAS

Brief overview of zooarchaeological research within the framework

of Middle Palaeolithic subsistence theories

MARIANA NABAIS

A distribuição espacial dos materiais líticos da UE003 do Rodo:

testemunho de reocupações do sítio ao longo do Tardiglaciar?

CRISTINA GAMEIRO, THIERRY AUBRY, BÁRBARA COSTA, SÉRGIO GOMES,

YANN LE JEUNE, CARMEN MANZANO, MAURIZIO ZAMBALDI

O sítio do Neolítico Antigo de Montum de Baixo (Melides - Alentejo Litoral)

JOAQUINA SOARES, CARLOS TAVARES DA SILVA, SUSANA DUARTE

A economia alimentar em Chibanes (Setúbal) - horizonte campaniforme

JOÃO LUÍS CARDOSO, CARLOS TAVARES DA SILVA, JOAQUINA SOARES, FILIPE MARTINS

Luto en la cara: ablaciones de duelo en el Mediterráneo Ancestral

ÁLVARO GÓMEZ PEÑA, JOSÉ LUIS ESCACENA CARRASCO

Dois conjuntos anfóricos do Castelo de São Jorge (Lisboa):

Largo de Santa Cruz do Castelo e Pátio José Pedreira

VICTOR FILIPE

A face romana de Santa Olaia (Figueira da Foz, Portugal) -

uma leitura possível a partir da cultura material

RICARDO COSTEIRA DA SILVA, SARA OLIVEIRA ALMEIDA, ISABEL PEREIRA

Cerâmica estampada britânica em Portugal (1780-1920).

Identidade, domesticidade e relações

TÂNIA CASIMIRO, INÊS CASTRO, TIAGO SILVA

Recensões bibliográficas

(TEXTOS: JOÃO LUÍS CARDOSO, ANA CATARINA SOUSA, VICTOR S. GONÇALVES,

FRANCISCO B. GOMES, PEDRO ALBUQUERQUE, LEYRE MORGADO-RONCAL)

Política editorial 


\title{
Dois conjuntos anfóricos do Castelo de São Jorge (Lisboa): Largo de Santa Cruz do Castelo e Pátio José Pedreira
}

\author{
Two amphorae assemblages \\ from Castelo de São Jorge (Lisbon): \\ Largo de Santa Cruz do Castelo \\ and Pátio José Pedreira
}

VICTOR FILIPE

UNIARQ - Centro de Arqueologia da Universidade de Lisboa victor.filipe7@gmail.com

ORCID iD: https://orcid.org/0000-0003-4356-5442

RESUMO: O espaço da antiga Alcáçova Islâmica do Castelo de Lisboa tem fornecido dados de extrema importância para o conhecimento dos momentos mais recuados da presença romana no Vale do Tejo. Nesse âmbito, têm-se destacado os estudos sobre os contentores anfóricos. Neste artigo apresenta-se a análise das ânforas romanas provenientes de duas intervenções arqueológicas realizadas naquela área da cidade: o Largo de Santa Cruz do Castelo e o Pátio José Pedreira. Com o estudo destes dois conjuntos anfóricos, procura-se reajustar e afinar o perfil de importação e consumo de géneros alimentares transportados em ânforas estabelecido para o alto do Morro do Castelo. Os dados destas amostras aportam algumas novidades importantes, de que se destaca a documentação da importação de vinho proveniente do Mediterrâneo oriental.

PALAVRAS-CHAVE: Olisipo, Tardo-República, Alcáçova Islâmica, ânforas, comércio romano.

ABSTRACT: The area of the ancient Islamic citadel of Lisbon Castle has provided extremely important data for the knowledge of the earliest moments of the Roman presence in the Tagus Valley. In this context, studies on amphorae containers have stood out. In this paper we present the analysis of the Roman amphorae from two archaeological interventions carried out in that area of the city: Largo de Santa Cruz do Castelo and Pátio José Pedreira. With the study of these two amphorae ensembles, we seek to readjust and improve the profile of importation and consumption of foodstuffs transported in amphorae established for the top of the Castle hill. The data from these samples provide some important new information, of which the documentation of wine imports from the eastern Mediterranean is noteworthy.

KEYWORDS: Olisipo, Late Republic, Islamic citadel, amphorae, Roman trade. 


\section{INTRODUÇÃO}

Entre os últimos anos do século passado e as duas primeiras décadas do século XXI, vários trabalhos arqueológicos realizados na antiga Alcáçova Islâmica de Lisboa têm colocado em evidência uma relevante ocupação republicana naquela área (Pimenta 2005), a par de importantes vestígios relacionados com o primitivo núcleo urbano sidérico (Sousa - Guerra 2018). Os contextos arqueológicos preservados apontam invariavelmente para o momento mais recuado da presença romana no extremo ocidente peninsular, cronologicamente associáveis à campanha militar de Décimo Júnio Bruto, em 138 a.C. (Pimenta 2014; Filipe 2018). As evidências são essencialmente constituídas por contextos de descarte de materiais, sendo raros os casos em que foram documentadas estruturas daquela época (Pimenta et al. 2014). Simultaneamente, são escassos os materiais e (ainda mais) os contextos romanos de época posterior.

No primeiro trabalho que colocou em evidência esta realidade (Pimenta 2005), destacou-se a documentação de grandes quantidades de contentores anfóricos, principalmente de ânforas vinárias da costa tirrénica de Itália (Greco-Itálicas e Dressel 1) e piscícolas da costa meridional da Ulterior (T-7.4.3.3.), e, em menor escala, vinárias e oleícolas da costa adriática itálica (Lamboglia 2 e ânforas de Brindisi) e oleícolas do Norte de África (Africana Antiga). Estes eram acompanhados por outros artigos importados, essencialmente de origem itálica, como as cerâmicas comuns e de verniz negro, as paredes finas, as lucernas e os numismas, bem como por cerâmica ibérica e cerâmica cinzenta de provável produção emporitana (Pimenta 2014; Pimenta - Ribera i Lacomba - Soria 2018).

Estes repertórios encontram paralelo nos de outros locais com comprovada presença militar romana durante o terceiro quartel do século II a.C., cujo paralelo mais paradigmático é constituído pela cidade de Valência (Ribera i Lacomba 2009). O comentado perfil de importação tem sido reiteradamente confirmado naquela zona da cidade em outras intervenções arqueológicas, notavelmente no Beco do Forno do Castelo (Pimenta et al. 2014) e de forma menos exuberante na Rua do Recolhimento (Mota - Pimenta - Silva 2014) e na Rua do Espírito Santo (Filipe et al. 2013; Filipe 2019), entre outros (Filipe 2019).
Todavia, mantêm-se ainda em aberto algumas questões relativamente à ocupação republicana no topo da Colina do Castelo, nomeadamente no que se refere ao perfil de importação de géneros alimentares transportados em ânforas, que aqui nos interessa directamente. Desde logo, destaca-se, nos conjuntos publicados, a ausência dos vinhos do Mediterrâneo oriental que, não obstante, estão documentados em Valentia e também em diversos outros locais da costa oriental e meridional da Península Ibérica (Ribera i Lacomba 2013; Pascual Berlanga - Pérez Ballester 2017). Foram, inclusivamente, já atestados no Vale do Tejo, em Scallabis, pela presença de ânforas Ródias (Bargão 2006), igualmente presentes em Valdetorres, na região de Badajoz (Heras Mora Bustamante Álvarez 2007). De igual forma, a escassez, por um lado, das variantes B e C da Dressel 1, por outro, das importações anfóricas dos dois quarteis centrais do século I a.C., então essencialmente compostas pelas produções do Vale do Guadalquivir e da costa meridional da Ulterior, que se encontram bem atestadas em toda a encosta da Colina do Castelo. Numa outra perspectiva, também a questão das proporções de alguns dos tipos anteriormente identificados, designadamente das imitações hispânicas de Greco-Itálicas e de Dressel 1, que apresentam, nestes dois conjuntos, percentagens diferenciadas relativamente aos já conhecidos.

Com a publicação dos conjuntos anfóricos do Largo de Santa Cruz do Castelo e do Pátio José Pedreira, sítios recentemente intervencionados e implantados em plena Alcáçova do Castelo (Fig. 1), procura-se contribuir para o esclarecimento de algumas das questões atrás enunciadas, complementando o panorama actual do conhecimento sobre os perfis de importação e de consumo em Olisipo durante a República. Embora com óbvias limitações sobretudo de carácter contextual, os dados destes dois sítios permitem não só ampliar o nosso conhecimento sobre a diversidade dos artigos importados, como também precisar algumas questões relacionadas com a ocupação do século I a.C. e com as proporções das ânforas documentadas naquela área da cidade.

$\mathrm{Na}$ estruturação deste trabalho, optou-se por apresentar de início o enquadramento do âmbito e localização das intervenções, bem como um breve comentário geral aos contextos estratigráficos dos sítios. Este é seguido de um comentário geral aos tipos documentados em ambos conjuntos, procurando-se sobretudo 


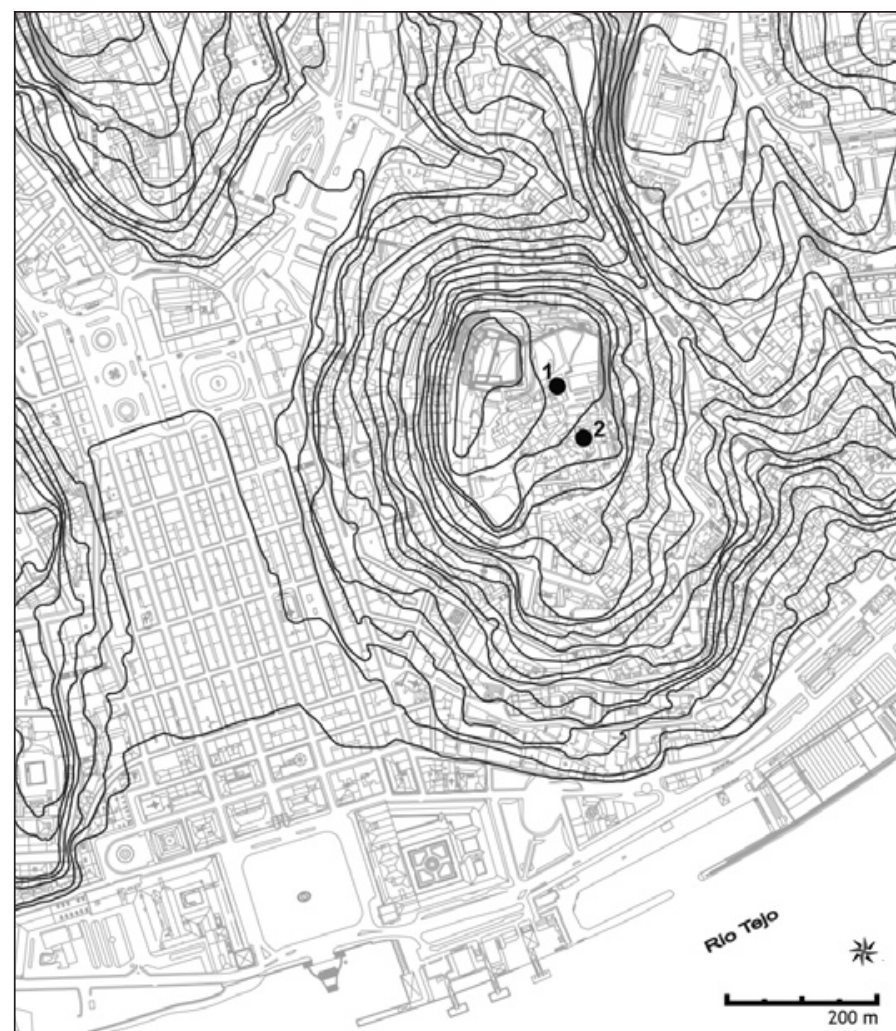

FIG. 1 Localização dos sítios na planta de Lisboa:

1 - Largo de Santa Cruz do Castelo:

2 - Pátio José Pedreira.

referir, no estado actual do conhecimento, as questões relacionadas com a cronologia de produção e comercialização, origem, conteúdo e disseminação no ocidente peninsular, particularmente no Vale do Tejo e em Olisipo. A terceira parte é dedicada à apreciação dos dois conjuntos anfóricos. Aqui, procedeu-se à análise quantitativa, apresentando-se as tabelas de quantificação por sítio, organizadas por origem e por conteúdo, comentando-se e procurando-se definir os perfis de importação e de consumo. Analisam-se ainda algumas questões relacionadas com os contextos estratigráficos de onde são procedentes os materiais, bem como a epigrafia anfórica do conjunto, que inclui marcas, tituli picti e grafitos.

\section{2. os SÍTIOS}

\subsection{Pátio José Pedreira}

Integrando diversos edifícios, o Pátio José Pedreira localiza-se em plena Alcáçova do Castelo de São Jorge, junto à área já intervencionada no Beco do Forno do
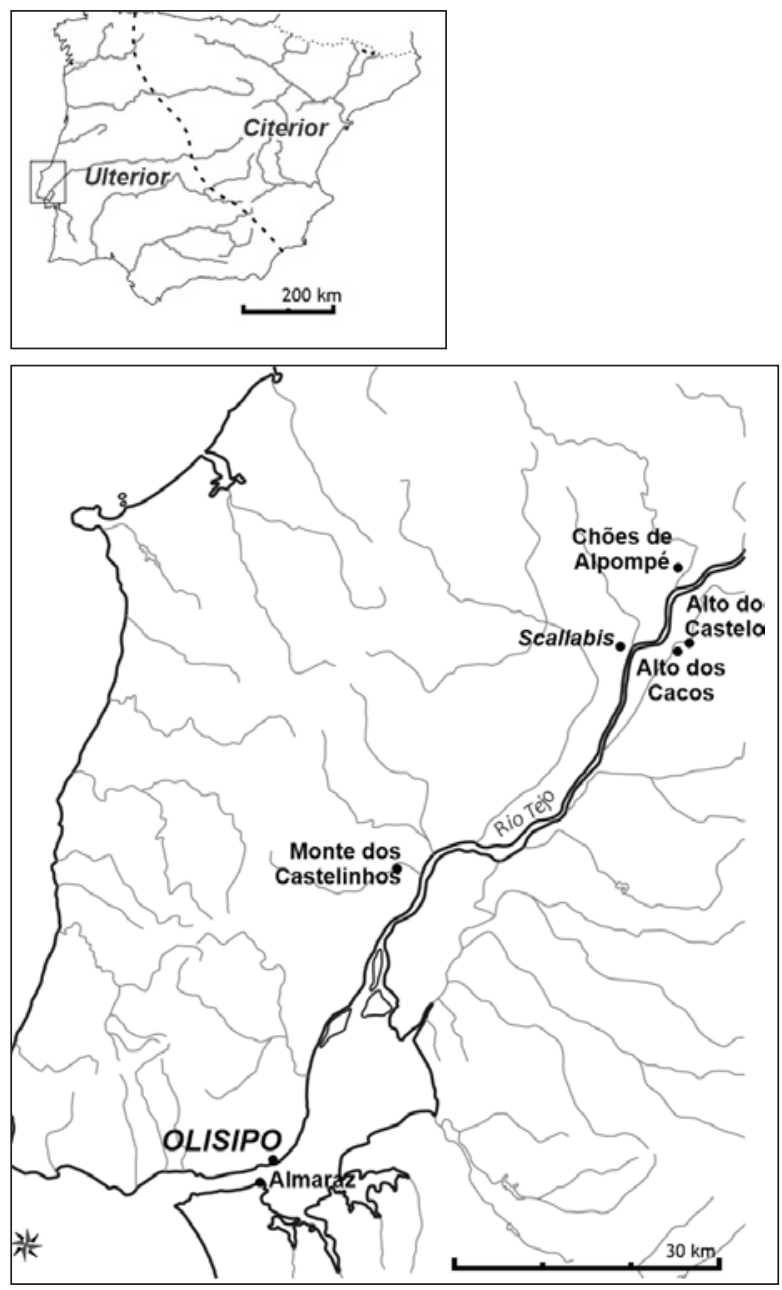

Castelo (Pimenta et al. 2014). A reabilitação do conjunto de imóveis ali situados foi enquadrada no Programa de Intervenção Prioritária em Acções de Reabilitação Urbana (PIPARU) da Câmara Municipal de Lisboa, no âmbito do qual foi desenvolvida uma intervenção arqueológica com o objectivo de minimizar os impactes sobre o património arqueológico. Os trabalhos de escavação foram efectuados em 2015, sob a responsabilidade de Anabela Joaquinito (Joaquinito 2017), tendo sido precedidos por uma intervenção de diagnóstico em 2011, então empreendida pela empresa ERA-Arqueologia e designada de Rua do Recolhimento, n. 35 (Sousa - Pinto 2016).

Durante a escavação de 2015 foram documentados importantes vestígios da ocupação naquela zona da cidade, abrangendo um lapso temporal que se estende da Idade do Ferro à época Contemporânea, incluindo, para além daqueles, contextos romanos, islâmicos, medievais e modernos. Infelizmente, os dados recolhidos durante a intervenção não se encontram ainda devidamente sistematizados, pelo que na 
generalidade dos contextos de Época Romana (que aqui directamente interessam) as cronologias avançadas são provisórias e principalmente baseadas na análise do conjunto anfórico, carecendo de confirmação posterior.

Existe, porém, uma excepção constituída por uma fossa de descarte, um contexto fechado, de onde provém um interessante conjunto de materiais, seguramente datável do terceiro quartel do século II a.C. (Edifício B, Compartimento 2, Vala Norte, UE [11]), de que adiante se falará mais detalhadamente.

\subsection{Largo de Santa Cruz do Castelo}

O Largo de Santa Cruz do Castelo situa-se no bairro histórico do Castelo, junto à Praça Nova, na área da antiga Alcáçova Islâmica da cidade de Lisboa. A intervenção arqueológica, realizada nos n. ${ }^{\circ} 6$ e 7, foi desencadeada pelo projecto de reabilitação daquele edifício, tendo os trabalhos de escavação sido realizados em 2010 e, intervaladamente, entre 2012 e 2016 sob a direcção científica de Sandra Guerra (Sousa Guerra 2018). O local havia já sido parcialmente intervencionado em 2001 (embora tenha então recebido distinta designação e CNS: Pátio do Sequeira, 18115) no âmbito dos trabalhos arqueológicos desenvolvidos durante a execução do Projecto Integrado do Castelo, que previa a reabilitação de um conjunto significativo de edifícios daquele bairro, trabalhos que foram cientificamente coordenados por Ana Gomes e Alexandra Gaspar. Durante essa intervenção os dados colectados referem-se sobretudo a contextos datados da Idade do Ferro, de que se destaca a documentação de um pavimento empedrado dessa época, não existindo menção à existência de níveis de época Romana (Gomes - Gaspar 2017).

Infelizmente, os contextos desta época registados durante as recentes escavações são de igual modo praticamente inexistentes, apesar da quantidade assinalável de materiais republicanos e, em menor medida, do Principado. Desafortunadamente, o expressivo conjunto anfórico deste sítio provém integralmente de níveis pós-romanos, sobretudo de aterros islâmicos. Paradoxalmente, preservaram-se no local importantes contextos e estruturas da Idade do Ferro, reveladoras da importante ocupação que durante esse período ali se registou (Guerra 2017; Sousa - Guerra 2018).

\section{TIPOLOGIAS E PROVENIÊNCIAS}

As importações de ânforas vinárias itálicas dominam em ambos conjuntos, destacando-se as que provêm da costa tirrénica. Entre estas, a Greco-Itálica corresponde ao modelo mais antigo, de inspiração grega, ocorrendo amiúde em contextos associados à expansão marítima de Roma durante a República (Fabião 1998). Embora produzidas desde o final do século IV a.C., as Greco-Itálicas só parecem ter chegado ao extremo ocidente peninsular no terceiro quartel do século II a.C., surgindo invariavelmente em âmbito de difusão militar, estando documentada apenas a variante mais tardia. Foram fabricadas na região centro e Sul da costa tirrénica da Península Itálica (Etrúria, Lácio e Campânia), bem como na costa adriática e na Sicília (Olcese 2011-2012; Rizzo 2014). Em Olisipo estão documentadas as produções tirrénicas e adriáticas, sendo estas últimas claramente minoritárias, constituindo-se a antiga Alcáçova Islâmica como o local onde se encontram melhor documentadas.

A fase de transição entre as produções mais tardias do tipo Greco-Itálico e as primeiras produções da Dressel 1, herdeira directa daquela, situa-se entre 140 e 130 a.C., correspondendo estas balizas cronológicas à presença romana mais antiga conhecida no Vale do Tejo, associada à campanha militar de Décimo Júnio Bruto. Estas duas formas foram produzidas nos mesmos centros produtores e comercializadas nos mesmos circuitos de distribuição, evidenciando uma evolução contínua (Pimenta 2005).

Quanto à Dressel 1, trata-se do contentor vinário itálico mais difundido durante a fase de conquista romana do Mediterrâneo Ocidental, estando registada a sua presença em grande parte do território nacional, com particular incidência no Vale do Tejo e em Olisipo, onde surgem em grandes quantidades. Quer nos dois conjuntos aqui em apreço, quer nos restantes locais de Lisboa onde se regista a presença desta forma, observa-se o predomínio da designada Dressel $1 \mathrm{~A}$ face às variantes B e C (Pimenta 2005; Filipe 2019). A Dressel 1 foi produzida em múltiplos centros oleiros da costa tirrénica da Península Itálica, entre os meados do terceiro quartel do século II a.C. e as décadas finais do século I a.C. (Peacock -Williams 1986; Tchernia 1986; Olcese 2011-2012).

Da costa adriática de Itália, para além das Greco-Itálicas a que se fez já referência, estão atestadas as 
Lamboglia 2 e as ânforas "de Brindisi", constituindo, em ambos casos, formas claramente minoritárias nos conjuntos em análise e na generalidade dos locais do ocidente peninsular. Relativamente às primeiras, trata-se de um contentor vinário que, à semelhança da Dressel 1, evolui a partir das Greco-Itálicas tardias, tendo sido produzida entre o final do século II a.C. e o terceiro quartel do século I a.C., principalmente nas regiões da Apúlia e do Véneto, embora também na costa tirrénica e possivelmente na Calábria, bem como na costa oriental do Adriático (Fabião 1987; Olcese 2011-2012; Bezeczky 2013; Rizzo 2014).

As ânforas "de Brindisi", destinadas a transportar azeite, correspondem a formas de influência helenística (Desy 1989; Opait 2010), surgindo recorrentemente nos conjuntos anfóricos republicanos de Olisipo e do restante ocidente peninsular, ainda que em quantidades discretas (Carreras Monfort et al. 2016; Mateo Corredor 2016; Filipe 2019). De dimensão relativamente modesta e corpo ovóide, apresentam uma certa diversidade formal, patente nas caracterizações tipológicas ensaiadas para as formas produzidas nas olarias de Apani, “La Rosa”, Marmorelle e Giancola, situadas na área da cidade de Brindisi, na Apúlia. Foram produzidas entre a segunda metade do século II a.C. e o Principado de Augusto, sendo sobretudo típicas da primeira metade do século I a.C. (Palazzo 2013).

Ainda relativamente às importações da Península Itálica, resta mencionar a presença das Dressel 2-4 da costa tirrénica, de que se reconheceu um único exemplar no conjunto do Largo de Santa Cruz do Castelo. Trata-se de uma ânfora que evoluiu a partir dos protótipos helenísticos com asas bífidas da ilha de Cos, tendo-se tornado na forma mais imitada do mundo romano (Peacock - Williams 1986; Empereur - Hesnard 1987). Embora considerada como sucessora da Dressel 1 no transporte dos vinhos itálicos, nunca alcançou nas províncias ocidentais os volumes de importação daquela (Fabião 1989). Foi produzida ao longo de toda a costa tirrénica da Península Itálica - Etrúria, Lácio, Campânia e Calábria - e também na costa adriática setentrional, central e meridional, desde o segundo quartel/meados do século I a.C. até finais do século || d.C. ou século III (Olcese 2011-2012; Bezeczky 2013; Rizzo 2014).

Produzidas entre os meados do século II a.C. e a época de Augusto, com o auge da sua comercialização centrado entre as últimas décadas do século II a.C. e a primeira metade do século I a.C., as típicas ânforas piscícolas da costa meridional da Ulterior, as T-7.4.3.3., constituem-se como um dos tipos mais representativos desta época no ocidente peninsular, estando particularmente bem documentados em Olisipo (Pimenta 2005; Filipe 2019). Trata-se de um modelo anfórico de tradição púnica, cujos centros de produção se localizavam sobretudo na Baía gaditana e no litoral da região de Málaga, estando a sua produção igualmente atestada no Vale do Guadalquivir, ainda que nesta última região em quantidades muito reduzidas (Lagóstena Barrios - Bernal Casasola 2004; Almeida 2008; Sáez Romero 2008).

Igualmente inspirada em modelos anfóricos de tradição púnica, a T-9.1.1.1. surge normalmente em quantidades reduzidas na cidade de Olisipo, estando documentada em ambos conjuntos aqui em consideração. Ânfora de pequena dimensão e com alguma variação morfológica, foi produzida entre os meados do século III a.C. e os primeiros decénios do século I a.C., sendo sobretudo típica da segunda metade do século II a.C. (Ramon Torres 1995; Sáez Romero 2008). O seu fabrico está amplamente atestado na baía gaditana (Sáez Romero 2008; Filipe 2010), existindo ainda indícios da sua produção na Baía de Algeciras (Bernal Casasola et al. 2011), na área de Málaga (Mateo Corredor 2014; Sáez Romero 2016) e em Ibiza (Ramon Torres 1995). A existência de estampilhas ostentando representações de atuns e de uma figura humana a envasar atum parece constituir fundamento suficiente para atribuir este tipo de contentores ao transporte de preparados piscícolas (Ramon Torres 1995; García Vargas 1998).

Também da costa meridional da Ulterior, estão documentadas no Largo de Santa Cruz do Castelo as imitações de Dressel 1, cujo fabrico se terá iniciado naquela região no terceiro quartel do século II e prolongado até ao terceiro quarto do século seguinte, podendo a produção de Dressel 1C ter-se estendido até aos últimos anos do século I a.C. ou primeiras décadas do século seguinte (Sáez Romero 2008; García Vargas et al. 2016). Ao contrário do modelo itálico, a imitação da Ulterior destinava-se a envasar produtos piscícolas, tendo sido documentados vestígios de preparados de peixe no interior de duas ânforas completas em Baelo Claudia (Bernal Casasola et al. 2003). Foi produzida na baía gaditana, na baía de Algeciras e no litoral de Málaga (García Vargas 1998; García Vargas 
et al. 2016). Embora com escassa representatividade estatística, estão bem documentadas em Olisipo, surgindo igualmente em outros locais do Vale do Tejo e do Algarve (Pimenta 2005; Viegas 2011; Filipe 2019).

De provável inspiração nos modelos ovóides apulo-adriáticos, a Classe 67/Ovóide 1 constitui-se como uma das mais antigas produções anfóricas da Bética, inserindo-se no vasto grupo de ânforas ovóides de produção e características tipicamente ocidentais. O arranque da sua produção terá ocorrido nos primeiros anos do segundo quartel do século I a.C. e prolongado até ao final dessa centúria ou início do século I d.C., situando-se o auge da sua comercialização no terceiro quartel do século I a.C. (Fabião 1989; 2001; Almeida 2008; García Vargas - Almeida - González Cesteros 2011). O principal foco de produção destes contentores situar-se-ia no Vale do Guadalquivir, tendo igualmente sido fabricadas no litoral da Bética - de onde provém o exemplar do Largo de Santa Cruz do Castelo - e na costa Atlântica de Marrocos (García Vargas - Almeida - González Cesteros 2011). Embora a questão do seu conteúdo não se encontre ainda totalmente esclarecida e se admita a possibilidade de terem sido utilizadas no transporte de distintos produtos, é provável que se destinassem principalmente a envasar azeite durante o auge da sua comercialização (García Vargas - Almeida - González Cesteros 2011; González Cesteros - Almeida - García Vargas 2016). Bem documentadas no Vale do Tejo, particularmente em Scallabis (Almeida 2008), as Classe 67/Ovóide 1 não são particularmente numerosas em Olisipo, ainda que se constituam, a par das Ovóide 4 e 6, como um dos tipos melhor representados para o período balizado entre os dois quarteis centrais do século I a.C. (Filipe 2019).

Assim designada a partir do estudo sobre as ânforas do Vale do Guadalquivir em Scallabis (Almeida 2008), a Ovóide 4 insere-se no grupo de contentores sud-hispânicos com significativo êxito comercial nos mercados ocidentais do século I a.C., correspondendo a um dos tipos do "núcleo morfológico e funcional" a partir do qual se desenvolveu o repertório anfórico da Bética do início da época Imperial, derivando na Haltern 70, um dos contentores de maior sucesso daquela província (García Vargas - Almeida - González Cesteros 2011). Foi produzida no Vale do Guadalquivir entre o segundo quartel do século I a.C. e o último terço dessa centúria, destinando-se muito provavelmente ao transporte de vinho e seus derivados. Relativamente à sua ocorrência em Olisipo e no Vale do Tejo, observa-se um panorama idêntico ao que se comentou para a Classe 67/Ovóide 1.

Quanto à Ovóide 5, assim denominada no estudo sobre os tipos minoritários do Vale do Guadalquivir documentados em Scallabis (Almeida 2008), a sua produção e comercialização ter-se-á iniciado um pouco antes de meados do século I a.C. estendendo-se até cerca de 15 a.C. e atingindo o auge durante o terceiro quartel desse século (Almeida 2008; García Vargas Almeida - González Cesteros 2011). Ainda que as evidências existentes não permitam esclarecer totalmente a questão, é provável que se destinasse a envasar azeite, não se devendo, contudo, descartar totalmente um conteúdo vínico (García Vargas - Almeida - González Cesteros 2011; 2016). Embora seja principalmente ao Vale do Guadalquivir que se atribui a sua produção, está igualmente atestado um fabrico na área costeira da Ulterior (García Vargas - Almeida - González Cesteros 2016). Estas produções do litoral estão presentes no Largo de Santa Cruz do Castelo, onde um dos dois exemplares identificados corresponde a uma produção da área de Málaga. De considerável menor êxito comercial que as suas contemporâneas Classe 67/Ovóide 1, Ovóide 4 e Ovóide 6, esta forma encontra-se escassamente documentada em Olisipo (Filipe 2019), surgindo igualmente em quantidades reduzidas em outros locais do Vale do Tejo, como o Monte dos Castelinhos (Pimenta - Mendes 2014), o Alto dos Cacos (Almeida Pimenta 2018) e Santarém (Almeida 2008), para além do exemplar recolhido no rio Tejo (Cardoso 2013).

A Haltern 70 é fundamentalmente um contentor do Vale do Guadalquivir e do Genil, embora também tivesse sido produzido em outras regiões (Berni Millet 2011). A sua produção e difusão parece situar-se entre meados do século I a.C., ou início do Principado de Augusto, e finais do século I d.C. ou primeiros anos do século II (Berni Millet 2011; García Vargas - Almeida González Cesteros 2011). Apesar de toda a polémica relacionada com o/os produto/s que se destinaria a transportar, a existência de diversos tituli picti demonstra que a Haltern 70 seria principalmente utilizada no transporte de vinho e seus derivados (Fabião 1998; Morais 2004). Está amplamente atestada no actual território português, com especial destaque para o noroeste (Morais 2004). Apesar de se registar apenas 
um exemplar atribuível a este tipo nos conjuntos aqui em apreço, encontra-se muito bem representada na cidade de Felicitas Iulia Olisipo (Filipe 2019).

Correspondendo a um dos tipos anfóricos romanos mais estudados e melhor conhecidos, a Dressel 20 foi principalmente produzida no Vale do Guadalquivir entre o segundo quartel do século I d.C. e o século III, destinando-se a transportar o azeite produzido naquela região da Baetica. Entre os principais aspectos que terão estimulado o seu estudo podem-se referir, por um lado, a sua produção e difusão em grande escala, de que o Monte Testaccio é eloquente testemunho, por outro, e talvez principalmente, a grande quantidade e variedade de informação epigráfica associada à sua produção e comercialização. Trata-se de uma forma que se desenvolveu a partir dos modelos oleícolas béticos de morfologia ovóide, as Oberaden 83 e as Haltern 71, evoluindo para uma ânfora de corpo globular e paredes grossas (Berni Millet 2008; García Vargas - Almeida - González Cesteros 2011). Encontrando-se muito bem documentada no actual território nacional, corresponde ao tipo extraprovincial melhor documentado em Olisipo (Filipe 2019). Ainda assim, é praticamente inexistente nos conjuntos anfóricos da antiga Alcáçova Islâmica do Castelo de São Jorge, estando, nos dois conjuntos aqui em análise, registado apenas no Largo de Santa Cruz do Castelo, onde surgiu um fragmento de asa com estampilha, datada da fase de Nero-Vespasiano.

A Africana Antiga corresponde a uma ânfora ovóide destinada a transportar azeite, tendo sido produzida na antiga Tripolitânia e na área da actual Tunísia (Capelli - Contino 2013). O seu fabrico ter-se-á iniciado em torno a meados do século II a.C., ou um pouco antes, estendendo-se até à época de Augusto e evoluindo ao longo desse período de tempo para contentores tendencialmente cilíndricos ou com o diâmetro máximo situado na sua metade inferior (Pascual Berlanga-Ribera i Lacomba 2002). A atribuição de um conteúdo oleícola a estes contentores relaciona-se essencialmente com as suas características morfológicas e directa associação às ânforas ovóides republicanas do Mediterrâneo, normalmente destinadas a transportar azeite, bem como à histórica relação da região da Tripolitânia com a produção oleícola (Benquet - Olmer 2002). Ainda que normalmente em quantidades modestas, está amplamente documentada no Mediterrâneo ocidental, surgindo no actual território português principalmente na costa algarvia e no Vale do Tejo (Filipe 2019).

A Dressel 4 de Cos, ou Ânfora Coa, surgiu na primeira metade do século III a.C., tendo evoluído ao longo do período helenístico até ao século I a.C. para uma forma mais alta e estreita, continuando a ser produzida em época Imperial até ao século II d.C. (Empereur - Hesnard 1987; Bezeczky 2013). Destinava-se a transportar os afamados vinhos de Cos, referidos nas fontes clássicas pela sua característica salinidade, em resultado de ser tratado com água do mar (Tchernia 1986; Bezeczky 2013). A difusão das Dressel 4 da ilha de Cos abarca preferencialmente o Mediterrâneo Oriental, ocorrendo em menores quantidades no Mediterrâneo Ocidental. No actual território português apenas se encontra documentada em contextos republicanos em Olisipo (Filipe 2019) e em Mértola.

Relativamente às Cretense 4/Dressel 43, de que apenas se identificou um fragmento de fundo no Largo de Santa Cruz do Castelo, trata-se de um contentor proveniente da ilha de Creta, produzido entre a primeira metade do século I d.C. e o século III, destinado a transportar vinho (Marangou-Lerat 1995; Bezeczky 2013). A sua presença é relativamente escassa na Península Ibérica, estando documentada no espaço da antiga província da Lusitânia apenas em Mérida (Almeida - Sánchez Hidalgo 2013), Idanha-a-Velha (Banha 2006) e Olisipo (Filipe 2019).

Quanto às produções locais/regionais de tradição pré-romana, estão atestados dois fragmentos de bordo no conjunto do Pátio José Pedreira atribuíveis ao Tipo 6 de E. Sousa e J. Pimenta (2014). As ocorrências mais antigas desta forma datam dos meados do 1.0 milénio a.C., estando atestadas em contextos dessa época na Rua dos Correeiros (Sousa 2014). Surgem em níveis do século III a.C. na Rua de São João da Praça (Pimenta - Calado - Leitão 2005) e já da segunda metade do século II a.C. no Castelo de São Jorge, neste caso associados a materiais republicanos (Pimenta 2005). Desconhece-se qual o produto que se destinariam a transportar. Quanto à sua difusão, o Tipo 6 parece estar atestado apenas na região do Vale do Tejo (Sousa Pimenta 2014).

Foi igualmente registada a presença das Lusitana Antiga, produzidas entre o terceiro quartel do século I a.C. e o terceiro quarto do século seguinte nos vales dos rios Sado e Tejo, embora, neste último caso, 
não se conheçam ainda os centros produtores (Filipe 2020). As escassas evidências directas actualmente existentes sobre os produtos que transportavam indicam um conteúdo piscícola (Oliveira - Morais - Araújo 2015; Morais - Oliveira - Araújo 2016). Embora a exportação para alguns locais do Mediterrâneo ocidental esteja atestada, a sua comercialização centrou-se principalmente no ocidente peninsular, constituindo-se Olisipo como o centro de consumo onde se encontra melhor documentada (Filipe 2019; 2020).

Quanto à Lusitana 3, de que se identificaram alguns fragmentos de fundo e asa em ambos conjuntos em análise, trata-se de um contentor de fundo plano, inspirado nos modelos da Gália, produzido abundantemente nas olarias dos vales dos rios Tejo e Sado entre o início do século II d.C. e meados do século III (Quaresma - Raposo 2016; Filipe 2021). A problemática relativa ao produto transportado por estes envases permanece em grande medida por resolver. A favor de um conteúdo vínico são normalmente apontadas as suas características morfológicas e a analogia à Gauloise 4, ânfora atestadamente vinária (Diogo 1987; Fabião 1998), bem como a existência de exemplares resinados e a não coincidência cronológica com a periodização das ânforas piscícolas lusitanas (Diogo - Alves 1988-1989). Encontra-se bem documentada no litoral e interior do Alentejo e nos vales dos rios Sado e Tejo, com particular incidência na cidade de Olisipo (Filipe 2019; 2021).

\section{ANÁLISE DOS CONJUNTOS}

\subsection{O conjunto anfórico do Pátio José Pedreira}

O conjunto do Pátio José Pedreira constitui-se como um dos mais representativos de época republicana na cidade de Lisboa, fornecendo alguns dados contextuais interessantes atribuíveis ao terceiro quartel do século II a.C. A amostra é composta por um total de 147 fragmentos de ânfora, bordos (54), fundos (22), asas (69) e duas paredes com grafito e titulus pictus, que se traduzem num Número Mínimo de 64 Indivíduos (Fig. 2). Destes, 89,06\% (57 NMI) correspondem a produções republicanas, 9,38\% (6 NMI) a ânforas do Principado e 1,56\% (1 NMI) a contentores de tipo indeterminado, estando totalmente ausentes as produções tardias (Figs. 3 e 4). Ainda que se constitua como uma amostra de escassa fiabilidade estatística, foram identificados 12 tipos fabricados em sete regiões produtoras distintas.

As importações republicanas são dominadas pelas produções da Península Itálica $(50,88 \%$ no seu conjunto), sendo representadas sobretudo pelas ânforas de tipo Greco-Itálico (48,28\% dos envases itálicos) e Dressel $1(24,14 \%)$ da costa tirrénica, e de forma mais modesta pelas produções da costa adriática $(7,02 \%$ do total de $\mathrm{NMI}$ ), de onde provêm algumas Greco-Itálicas (10,34\% dos itálicos) e uma ânfora de Brindisi (3,45\%). Foram ainda registados quatro indivíduos indistintamente classificados de Greco-Itálica/Dressel 1, significando $13,79 \%$ das ânforas itálicas. No âmbito destas produções, não deixa de ser assinalável o alto índice de Greco-Itálicas, remetendo para o momento mais recuado da presença romana em Olisipo (Fig. 3).

A costa meridional da Ulterior surge como a segunda região mais importante $(38,6 \%)$ no quadro das importações, sendo maioritariamente representada pelas T-7.4.3.3. (95,45\% dessa região) e de forma pouco expressiva pelas T-9.1.1.1. (4,55\%). Da mesma província, surgem representadas as áreas produtoras dos vales do Tejo e Sado (3,51\% do total NMI) e do Vale do Guadalquivir (1,75\%), ambas com um peso estatístico reduzido na amostra. Da primeira região foram identificados dois indivíduos tipologicamente enquadráveis nas produções locais/regionais de tradição pré-romana de Tipo 6, recentemente sistematizadas (Sousa - Pimenta 2014), recolhidos em contexto possivelmente datado da segunda metade do século I a.C. Do Vale do Guadalquivir apenas se reconheceu um fragmento de bordo de uma Ovóide 4 em nível pós-romano. Já do Norte de África foram documentados dois indivíduos de Africana Antiga, significando 3,51\% das ânforas republicanas. Por fim, o Mediterrâneo Oriental representa 1,75\% das importações, registando-se a importante e até agora desconhecida presença do vinho da ilha de Cos no alto do morro do Castelo através de uma asa bífida com o fabrico típico daquela ilha, ostentando marca de oleiro em caracteres gregos (Fig. 7).

Em relação aos produtos envasados nestes contentores, o vinho domina totalmente, significando $52,63 \%$ da amostra (Fig. 4). Este precioso líquido era importado sobretudo da costa tirrénica da Península Itálica (83,33\% das ânforas vinárias) nas ânforas de tipo Greco-Itálico (46,7\%) e Dressel 1 (23,33\%) (a que se deverão adicionar 13,33\% indistintamente 
FIG. 2 Quantificação global das ânforas do Pátio José Pedreira.

\begin{tabular}{|c|c|c|c|c|c|c|c|c|}
\hline PROVENIEENCIA & TIPO & TF & $\% \mathrm{TF}$ & NMI & $\% \mathrm{NMI}$ & $\begin{array}{l}\% \text { NMI } \\
\text { REGIÄO }\end{array}$ & $\begin{array}{c}\text { \% NMI } \\
\text { PROVÍNCIA }\end{array}$ & $\begin{array}{c}\% \mathrm{NMI} \\
\text { EXTRAPROV }\end{array}$ \\
\hline \multirow{4}{*}{ Lusitânia, Tejo/Sado } & Lusitana Antiga & 1 & $0,68 \%$ & 1 & $1,56 \%$ & $25 \%$ & $25 \%$ & \\
\hline & Lusitana Antiga/Dressel 14 & 1 & $0,68 \%$ & 1 & $1,56 \%$ & $25 \%$ & $16,67 \%$ & \\
\hline & Lusitana 3 & 4 & $2,72 \%$ & 2 & $3,13 \%$ & $50 \%$ & $50 \%$ & \\
\hline & Total & 6 & $4,08 \%$ & 4 & $6,25 \%$ & $100 \%$ & $92 \%$ & \\
\hline \multirow{3}{*}{$\begin{array}{l}\text { Bética, Vale do } \\
\text { Guadalquivir }\end{array}$} & Ovóide indeterminada & 3 & $2,04 \%$ & 1 & $1,56 \%$ & $50 \%$ & $50 \%$ & $1,75 \%$ \\
\hline & Haltern 70 & 1 & $0,68 \%$ & 1 & $1,56 \%$ & $50 \%$ & $50 \%$ & $1,75 \%$ \\
\hline & Total & 4 & $2,72 \%$ & 2 & $3,13 \%$ & $100 \%$ & $100 \%$ & $3,51 \%$ \\
\hline \multirow{2}{*}{$\begin{array}{l}\text { Hispânia Ulterior, } \\
\text { Tejo/Sado }\end{array}$} & Tipo 6 & 2 & $1,36 \%$ & 2 & $3,13 \%$ & $100 \%$ & $8 \%$ & \\
\hline & Total & 2 & $1,36 \%$ & 2 & $3,13 \%$ & $100 \%$ & & \\
\hline \multirow{3}{*}{$\begin{array}{l}\text { Hispânia Ulterior, } \\
\text { costa meridional }\end{array}$} & T-7.4.3.3. & 36 & $24,49 \%$ & 21 & $32,81 \%$ & $95,45 \%$ & $84 \%$ & $36,84 \%$ \\
\hline & T-9.1.1.1. & 1 & $0,68 \%$ & 1 & $1,56 \%$ & $4,55 \%$ & $4 \%$ & $1,28 \%$ \\
\hline & Total & 37 & $25,17 \%$ & 22 & $34,38 \%$ & $100 \%$ & & $38,12 \%$ \\
\hline \multirow{2}{*}{$\begin{array}{l}\text { Hispânia Ulterior, } \\
\text { Vale do Guadalquivir }\end{array}$} & Ovóide 4 & 1 & $0,68 \%$ & 1 & $1,56 \%$ & $100 \%$ & $4,35 \%$ & $1,75 \%$ \\
\hline & Total & 1 & $0,68 \%$ & 1 & $1,56 \%$ & $100 \%$ & $100 \%$ & $1,75 \%$ \\
\hline \multirow{4}{*}{$\begin{array}{l}\text { Península Itálica, } \\
\text { costa tirrénica }\end{array}$} & Greco-Itálica & 14 & $9,52 \%$ & 14 & $21,88 \%$ & $56 \%$ & $48,28 \%$ & $24,56 \%$ \\
\hline & Dressel 1 & 8 & $5,44 \%$ & 7 & $10,94 \%$ & $28 \%$ & $24,14 \%$ & $12,28 \%$ \\
\hline & Greco-Itálica/Dressel 1 & 66 & $44,90 \%$ & 4 & $6,25 \%$ & $16 \%$ & $13,79 \%$ & $7,02 \%$ \\
\hline & Total & 88 & $59,86 \%$ & 25 & $39,06 \%$ & $100 \%$ & & $43,86 \%$ \\
\hline \multirow{3}{*}{$\begin{array}{l}\text { Península Itálica, } \\
\text { costa adriática }\end{array}$} & Greco-Itálica & 4 & $2,72 \%$ & 3 & $4,69 \%$ & $75 \%$ & $10,34 \%$ & $5,26 \%$ \\
\hline & Brindisi & 1 & $0,68 \%$ & 1 & $1,56 \%$ & $25 \%$ & $3,45 \%$ & $1,75 \%$ \\
\hline & Total & 5 & $3,4 \%$ & 4 & $6,25 \%$ & $100 \%$ & $100 \%$ & $7,02 \%$ \\
\hline \multirow{2}{*}{ Norte de África } & Africana Antiga & 2 & $1,36 \%$ & 2 & $3,13 \%$ & $100 \%$ & $100 \%$ & $3,51 \%$ \\
\hline & Total & 2 & $1,36 \%$ & 2 & $3,13 \%$ & $100 \%$ & $100 \%$ & $3,51 \%$ \\
\hline \multirow{2}{*}{ Mediterrâneo Oriental } & Dressel 4 de Cos & 1 & $0,68 \%$ & 1 & $1,56 \%$ & $100 \%$ & $100 \%$ & $1,75 \%$ \\
\hline & Total & 1 & $0,68 \%$ & 1 & $1,56 \%$ & $100 \%$ & $100 \%$ & $1,75 \%$ \\
\hline \multirow{2}{*}{ Indeterminada } & Indeterminado & 1 & $0,68 \%$ & 1 & $1,56 \%$ & $100 \%$ & $100 \%$ & \\
\hline & Total & 1 & $0,68 \%$ & 1 & $1,56 \%$ & $100 \%$ & $100 \%$ & \\
\hline TOTAL & & 147 & $100 \%$ & 64 & $100 \%$ & & & $100 \%$ \\
\hline
\end{tabular}

classificadas como Greco-Itálica/Dressel 1); mas também da costa adriática (10\%), exclusivamente em Greco-Itálicas, e, em idênticas percentagens (3,33\%), do Vale do Guadalquivir, nas Ovóide 4, e do Mediterrâneo Oriental, nas Dressel 4 de Cos.

Já os preparados piscícolas, significando 38,6\% dos bens alimentares transportados em ânforas durante esta fase, provêm exclusivamente da costa meridional da Ulterior, sendo transportados nas T-7.4.3.3. (95,45\% desse produto) e T-9.1.1.1. (4,55\%). O azeite constitui-se claramente como o produto menos importante no quadro das importações republicanas, significando apenas 5,26\% dos envases desse período. Era importado da região líbia e tunisina nas designadas Africana
Antiga (66,67\% desses envases) e do Sul da Península Itálica nas ânforas de Brindisi (33,33\%).

Em termos gerais, e apesar de ser quantitativamente pouco expressiva, as proporções que se verificam nesta amostra não se afastam muito do quadro de consumo global da cidade de Lisboa, notando-se sobretudo uma menor representação do azeite e uma ligeira subida das percentagens dos preparados piscícolas e do vinho. O perfil de consumo enquadra-se, ainda que com ligeiras diferenças, no que era já conhecido para a área da antiga Alcáçova Islâmica (Pimenta 2005), definindo um padrão próprio desta zona da cidade que difere do que se observa na encosta Sul, por exemplo, no importante conjunto da Sé Catedral (Filipe 2019). 
FIG. 3 Quantificação das ânforas republicanas do Pátio José Pedreira.

\begin{tabular}{|c|c|c|c|c|c|c|c|c|}
\hline PROVENIÊNCIA & TIPO & TF & $\% \mathrm{TF}$ & NMI & $\% \mathrm{NMI}$ & $\begin{array}{c}\% \text { NMI } \\
\text { REGIÃO }\end{array}$ & $\begin{array}{c}\% \text { NMI } \\
\text { PROVÍNCIA }\end{array}$ & $\begin{array}{c}\% \text { NMI } \\
\text { EXTRAPROV. }\end{array}$ \\
\hline \multirow{2}{*}{$\begin{array}{l}\text { Hispânia Ulterior, } \\
\text { Tejo/Sado }\end{array}$} & Tipo 6 & 2 & $1,47 \%$ & 2 & $3,51 \%$ & $100 \%$ & $8 \%$ & \\
\hline & Total & 2 & $1,47 \%$ & 2 & $3,51 \%$ & $100 \%$ & & \\
\hline \multirow{3}{*}{$\begin{array}{l}\text { Hispânia Ulterior, } \\
\text { costa meridional }\end{array}$} & T-7.4.3.3. & 36 & $26,47 \%$ & 21 & $36,84 \%$ & $95,45 \%$ & $84 \%$ & $38,18 \%$ \\
\hline & T-9.1.1.1. & 1 & $0,74 \%$ & 1 & $1,75 \%$ & $4,55 \%$ & $4 \%$ & $1,82 \%$ \\
\hline & Total & 37 & $27,21 \%$ & 22 & $38,6 \%$ & $100 \%$ & & $40 \%$ \\
\hline \multirow{2}{*}{$\begin{array}{l}\text { Hispânia Ulterior, } \\
\text { Vale do Guadalquivir }\end{array}$} & Ovóide 4 & 1 & $0,74 \%$ & 1 & $1,75 \%$ & $100 \%$ & $4 \%$ & $1,82 \%$ \\
\hline & Total & 1 & $0,74 \%$ & 1 & $1,75 \%$ & $100 \%$ & $100 \%$ & $1,82 \%$ \\
\hline \multirow{4}{*}{$\begin{array}{l}\text { Península Itálica, } \\
\text { costa tirrénica }\end{array}$} & Greco-Itálica & 14 & $10,29 \%$ & 14 & $24,56 \%$ & $56 \%$ & $48,28 \%$ & $25,45 \%$ \\
\hline & Dressel 1 & 8 & $5,88 \%$ & 7 & $12,28 \%$ & $28 \%$ & $24,14 \%$ & $12,73 \%$ \\
\hline & Greco-Itálica/Dressel 1 & 66 & $48,53 \%$ & 4 & $7,02 \%$ & $16 \%$ & $13,79 \%$ & $7,27 \%$ \\
\hline & Total & 88 & $64,71 \%$ & 25 & $43,86 \%$ & $100 \%$ & & $45,45 \%$ \\
\hline \multirow{3}{*}{$\begin{array}{l}\text { Península Itálica, } \\
\text { costa adriática }\end{array}$} & Greco-Itálica & 4 & $2,94 \%$ & 3 & $5,26 \%$ & $75 \%$ & $10,34 \%$ & $5,45 \%$ \\
\hline & Brindisi & 1 & $0,74 \%$ & 1 & $1,75 \%$ & $25 \%$ & $3,45 \%$ & $1,82 \%$ \\
\hline & Total & 5 & $3,68 \%$ & 4 & $7,02 \%$ & $100 \%$ & $100 \%$ & $7,27 \%$ \\
\hline \multirow{2}{*}{ Norte de África } & Africana Antiga & 2 & $1,47 \%$ & 2 & $3,51 \%$ & $100 \%$ & $100 \%$ & $3,64 \%$ \\
\hline & Total & 2 & $1,47 \%$ & 2 & $3,51 \%$ & $100 \%$ & $100 \%$ & $3,64 \%$ \\
\hline \multirow{2}{*}{ Mediterrâneo Oriental } & Dressel 4 de Cos & 1 & $0,74 \%$ & 1 & $1,75 \%$ & $100 \%$ & $100 \%$ & $1,82 \%$ \\
\hline & Total & 1 & $0,74 \%$ & 1 & $1,75 \%$ & $100 \%$ & $100 \%$ & $1,82 \%$ \\
\hline TOTAL & & 136 & $100 \%$ & 57 & $100 \%$ & & & $100 \%$ \\
\hline
\end{tabular}

Apesar de, na sua maioria, os contentores anfóricos do pátio José Pedreira terem sido exumados em contextos posteriores à sua época de produção e circulação, os dados contextuais do conjunto são, ainda assim, relevantes. Particularmente expressivo é o conjunto datado do terceiro quartel do século II a.C. recoIhido no interior de uma fossa de descarte situada no edifício $B$, que infelizmente não foi possível escavar na sua totalidade (Figs. 5 e 6 ).

Aí verificou-se a associação de Greco-Itálicas (que compunham $60 \%$ das ânforas do contexto) com Dressel $1 \mathrm{~A}$ e de transição (30\%) e com um exemplar completo de Africana Antiga, de perfil marcadamente ovóide e aparentemente imputável a um momento antigo da sua produção. Da mesma cronologia parece ser o contexto de onde provém o bocal de Greco-Itálica n. ${ }^{\circ}$ 2554.01, na sondagem 1 do mesmo edifício (Fig. 7). De cronologia menos fina, genericamente balizada entre o terceiro quartel do século II a.C. e o segundo terço da centúria seguinte, são alguns contextos documentados no edifício B1, onde se recolheram Greco-Itálicas, Dressel 1, T-7.4.3.3. e o Tipo VIIA de Apani.
Menos clara é a cronologia da formação do depósito [12] da sondagem 1 deste último edifício onde, a par de um expressivo conjunto anfórico (60 fragmentos) genericamente enquadrável na segunda metade do século I a.C. e composto por contentores do tipo Greco-Itálico, variantes A e C da Dressel 1, Dressel 4 de Cos, T-9.1.1.1., ânforas ovóides do Guadalquivir de tipo indeterminado, um bordo de Lusitana Antiga e ânforas de tradição púnica de produção local/regional, foram recolhidos dois fragmentos de Lusitana 3. Apenas a sistematização de todos os dados permitirá afinar a cronologia deste contexto e esclarecer se estamos perante um nível já do século II d.C. (ou posterior...) com um índice alto de residualidade ou se, pelo contrário, os dois fragmentos de Lusitana 3 poderão corresponder a intrusões na estratigrafia. Considerando esta segunda possibilidade, será bem provável que o contexto date do terceiro quartel do século I a.C. sobretudo tendo em conta a baixa percentagem de produções do Guadalquivir e a importante representação das Dressel 1 e das T-7.4.3.3. A confirmar-se esta hipótese, este contexto seria um dos 
FIG.4 Quantificação por conteúdo das ânforas republicanas do Pátio José Pedreira.

\begin{tabular}{|c|c|c|c|c|c|c|c|}
\hline CONTEÚDO & PROVENIÊNCIA & TIPO & NMI & $\% \mathrm{NMI}$ & $\begin{array}{c}\text { \% NMI } \\
\text { CONTEÚDO } \\
\text { REGIÄO }\end{array}$ & $\begin{array}{c}\% \text { NMI } \\
\text { CONTEÚDO } \\
\text { PROVÍNCIA }\end{array}$ & $\begin{array}{c}\% \text { NMI } \\
\text { CONTEÚDO }\end{array}$ \\
\hline \multirow{4}{*}{$\begin{array}{l}\text { Preparados } \\
\text { piscícolas }\end{array}$} & \multirow{3}{*}{$\begin{array}{l}\text { Hispânia Ulterior, } \\
\text { costa meridional }\end{array}$} & T-7.4.3.3. & 21 & $36,84 \%$ & $95,45 \%$ & $95,45 \%$ & $95,45 \%$ \\
\hline & & T-9.1.1.1. & 1 & $1,75 \%$ & $4,55 \%$ & $4,55 \%$ & $4,55 \%$ \\
\hline & & Total & 22 & $38,6 \%$ & $100 \%$ & $100 \%$ & $100 \%$ \\
\hline & TOTAL & & 22 & $38,6 \%$ & & & $100 \%$ \\
\hline \multirow{11}{*}{$\begin{array}{l}\text { Vinho } \\
\text { e derivados }\end{array}$} & \multirow{2}{*}{$\begin{array}{l}\text { Hispânia Ulterior, } \\
\text { Vale do Guadalquivir }\end{array}$} & Ovóide 4 & 1 & $1,75 \%$ & $100 \%$ & $100 \%$ & $3,33 \%$ \\
\hline & & Total & 1 & $1,75 \%$ & $100 \%$ & $100 \%$ & $3,33 \%$ \\
\hline & \multirow{4}{*}{$\begin{array}{l}\text { Península Itálica, } \\
\text { costa tirrénica }\end{array}$} & Greco-Itálica & 14 & $24,56 \%$ & $56 \%$ & $50 \%$ & $46,7 \%$ \\
\hline & & Dressel 1 & 7 & $12,28 \%$ & $28 \%$ & $25 \%$ & $23,33 \%$ \\
\hline & & Greco-Itálica/Dressel 1 & 4 & $7,02 \%$ & $16 \%$ & $14,29 \%$ & $13,33 \%$ \\
\hline & & Total & 25 & $43,86 \%$ & $100 \%$ & & $83,33 \%$ \\
\hline & \multirow{2}{*}{$\begin{array}{l}\text { Península Itálica, } \\
\text { costa adriática }\end{array}$} & Greco-Itálica & 3 & $5,26 \%$ & $100 \%$ & $10,71 \%$ & $10 \%$ \\
\hline & & Total & 3 & $5,26 \%$ & $100 \%$ & $100 \%$ & $10 \%$ \\
\hline & \multirow{2}{*}{ Mediterrâneo Oriental } & Dressel 4 de Cos & 1 & $1,75 \%$ & $100 \%$ & $100 \%$ & $3,33 \%$ \\
\hline & & Total & 1 & $1,75 \%$ & $100 \%$ & $100 \%$ & $3,33 \%$ \\
\hline & TOTAL & & 30 & $52,63 \%$ & & & $100 \%$ \\
\hline \multirow{5}{*}{ Azeite } & \multirow{2}{*}{$\begin{array}{l}\text { Península Itálica, } \\
\text { costa adriática }\end{array}$} & Brindisi & 1 & $1,75 \%$ & $100 \%$ & $100 \%$ & $33,33 \%$ \\
\hline & & Total & 1 & $1,75 \%$ & $100 \%$ & $100 \%$ & $33,33 \%$ \\
\hline & \multirow{2}{*}{ Norte de África } & Africana Antiga & 2 & $3,51 \%$ & $100 \%$ & $100 \%$ & $66,67 \%$ \\
\hline & & Total & 2 & $3,51 \%$ & $100 \%$ & $100 \%$ & $66,67 \%$ \\
\hline & TOTAL & & 3 & $5,26 \%$ & & & $100 \%$ \\
\hline \multirow{3}{*}{ Indeterminada } & \multirow{2}{*}{$\begin{array}{l}\text { Hispânia Ulterior, } \\
\text { Tejo/Sado }\end{array}$} & Tipo 6 & 2 & $3,51 \%$ & $100 \%$ & $100 \%$ & $100 \%$ \\
\hline & & Total & 2 & $3,51 \%$ & $100 \%$ & $100 \%$ & $100 \%$ \\
\hline & TOTAL & & 2 & $3,51 \%$ & & & $100 \%$ \\
\hline TOTAL & & & 57 & $100 \%$ & & & \\
\hline
\end{tabular}

mais antigos conhecidos com presença das mais precoces produções anfóricas tipicamente romanas da Lusitania ou extremo ocidente ibérico, comprovando a sua produção em momentos anteriores ao Principado de Augusto.

Já a unidade [27] $(B, 1)$ parece atestar a ocupação do local durante a fase imperial, provavelmente durante $\mathrm{o}$ século II ou III d.C., uma vez que o grau de preservação da Lusitana 3 aí exumada (Fig. 8, n. ${ }^{\circ}$ 1491.01) e a existência de diversas colagens na mesma afasta qualquer hipótese de infiltração.

Em termos gerais, o conjunto apresenta um perfil marcadamente antigo, isto é, em boa parte enquadrável ainda no século II a.C., sendo a representação das Greco-Itálicas ( $24,56 \%$ dos envases republicanos) bastante ilustrativa quanto a esse aspecto, bem como os contextos datados dessa fase. Embora bastante completo no que se refere à diversidade de origens e de tipos, nota-se, ainda assim, a ausência de formas como a Dressel 1 da costa meridional da Ulterior e da Lamboglia 2 da costa adriática da Península Itálica. Embora em menor medida, os materiais e os contextos estratigráficos apresentam igualmente alguns testemunhos da ocupação daquela área durante o século I a.C., particularmente as designadas Dressel 1B e C, as Ovóide 4 do Guadalquivir e as produções locais/regionais; bem como do Alto-Império, através da presença de contentores como a Haltern 70 do Guadalquivir e a Lusitana 3. 


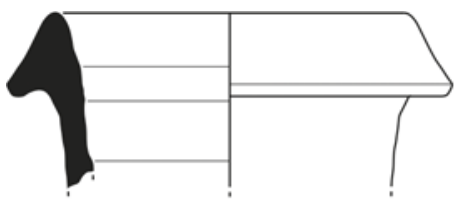

2444.17

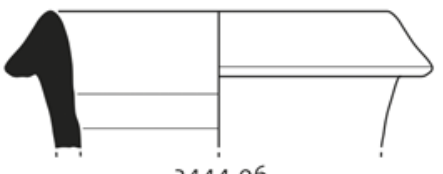

2444.06
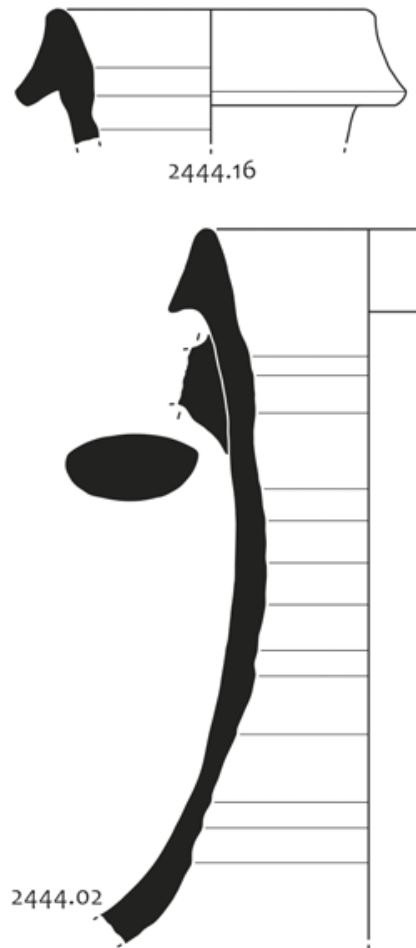
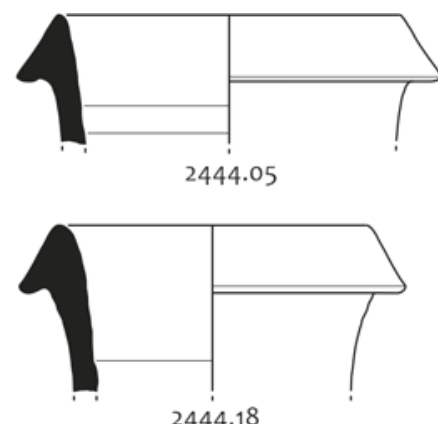

2444.18

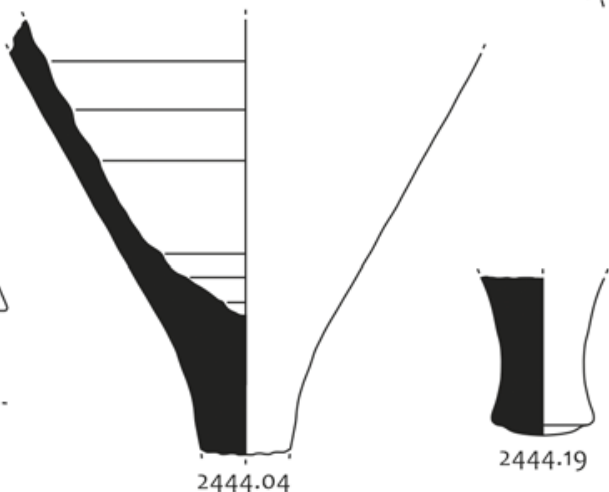

2444.04

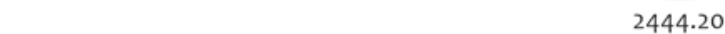

2444.15

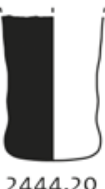

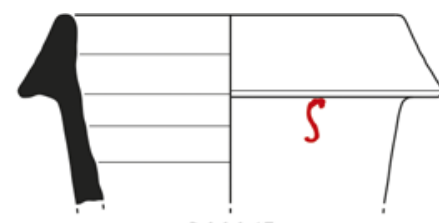
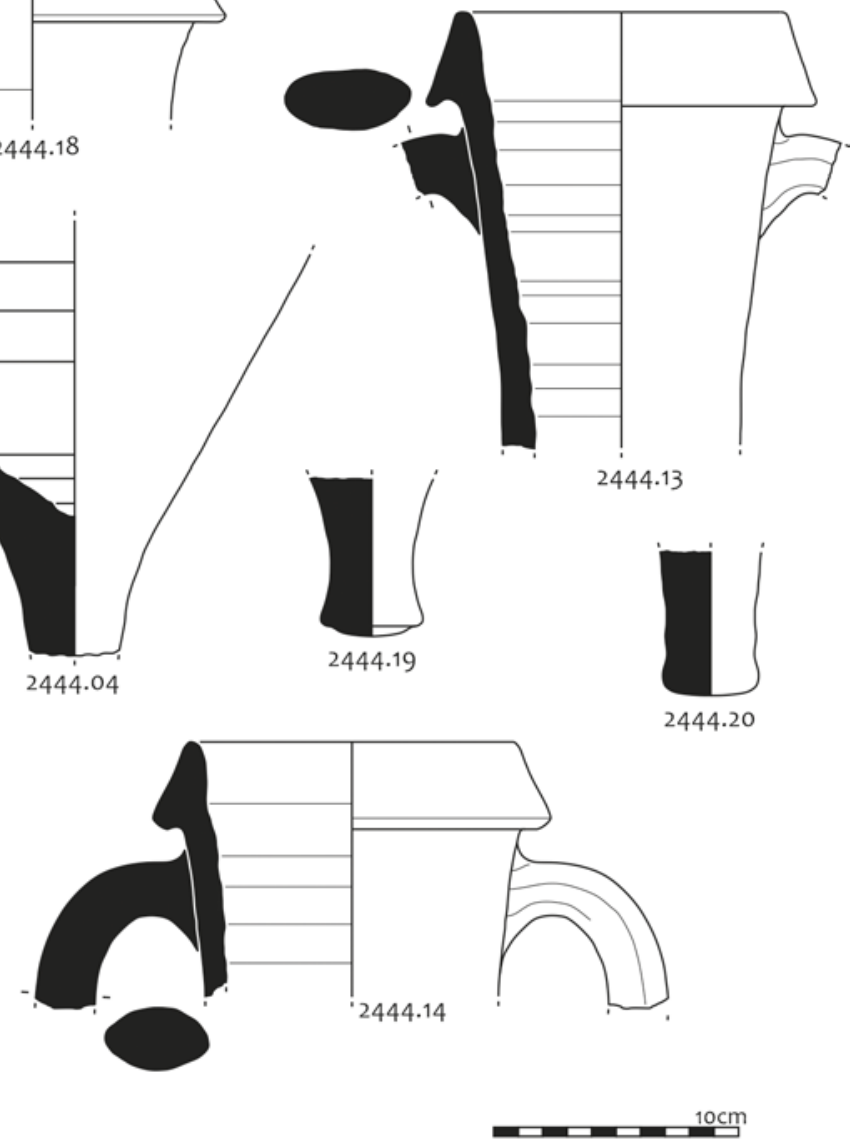

FIG. 5 Pátio José Sequeira. Contexto (fossa) datado do terceiro quartel do século Il a.C. Península Itálica, costa adriática: Greco-Itálica (2444.05, 2444.16). Península Itálica, costa tirrénica: Greco-Itálica (2444.02, 2444.06, 2444.17, 2444.18), Dressel 1 (2444.15, 2444.13, 2444.14, 2444.01), Greco-Itálica/Dressel 1 (2444.04, 2444.20, 2444.19).
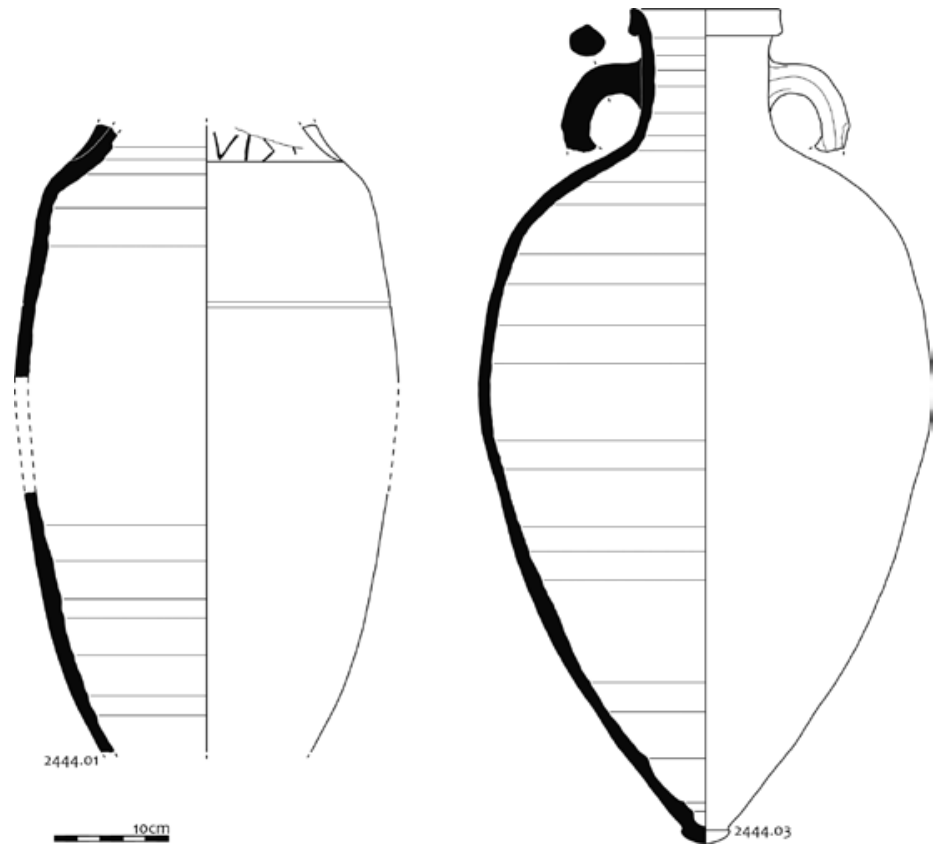

FIG. 6 Pátio José Sequeira. Contexto (fossa) datado do terceiro quartel do século II a.C. Península Itálica, costa tirrénica: Dressel 1 (2444.01). Norte de África: Africana Antiga (2444.03). 

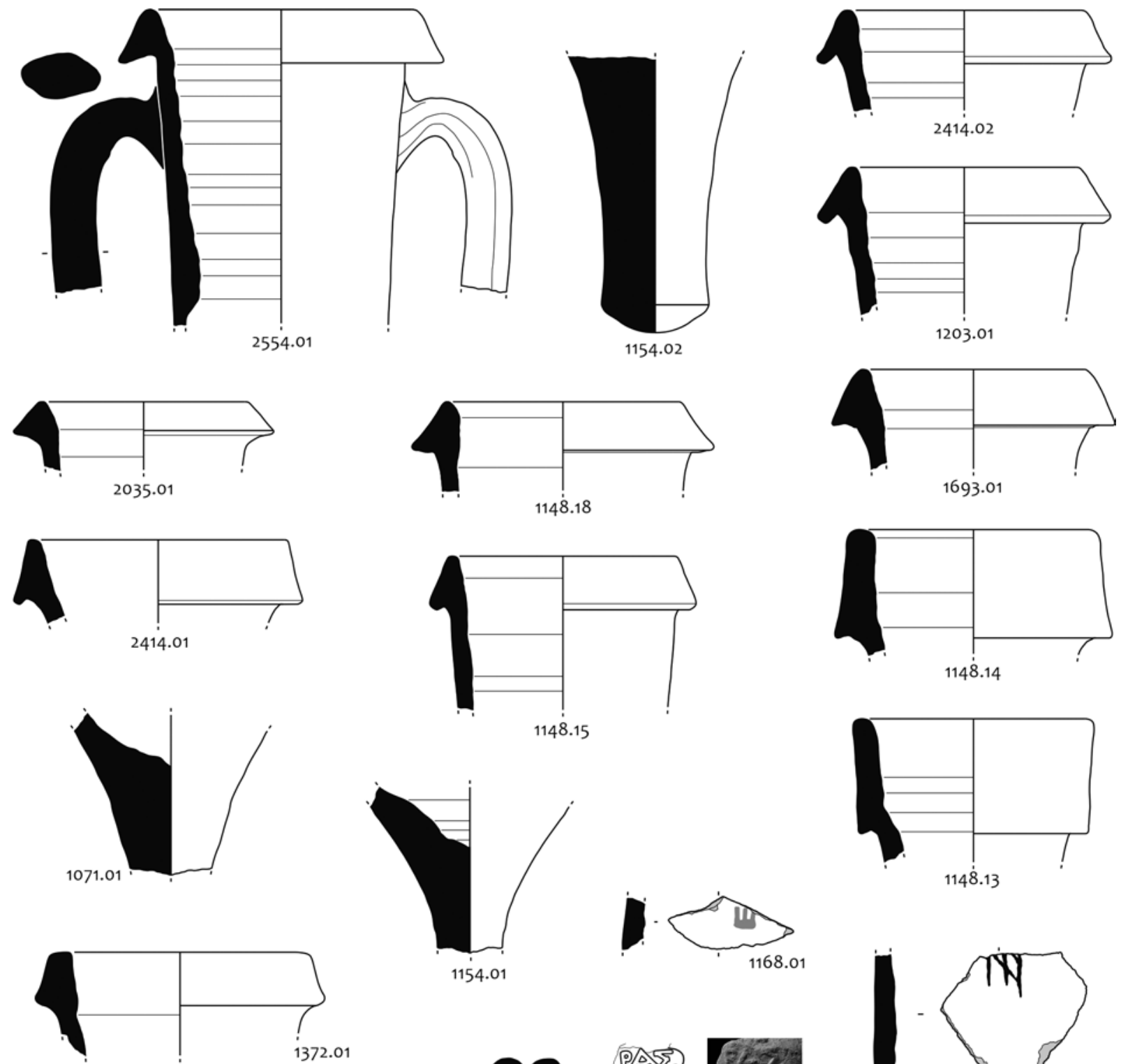

372.01
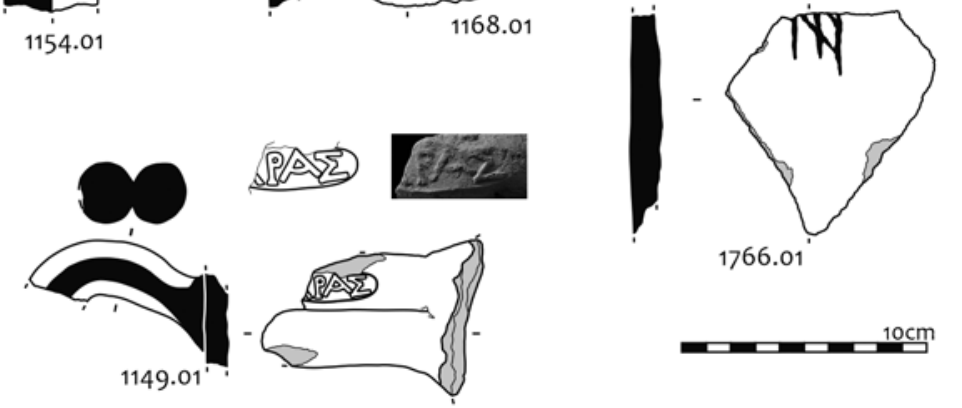

FIG. 7 Pátio José Sequeira. Península Itálica, costa tirrénica: Greco-Itálica (2414.02, 1203.01, 2035.01, 1148.18, 1693.01, 2554.01), Dressel 1 (2414.01, 1148.15, 1148.14, 1148.13), Greco-Itálica/Dressel 1 (1154.02, 1071.01, 1154.01, 1168.01, 1766.01). Península Itálica, costa adriática: Ânfora de Brindisi, Apani VIIA (1372.01). Norte de África: Africana Antiga (1148.02). Mediterrâneo oriental: Dressel 4 de Cos (1149.01). 

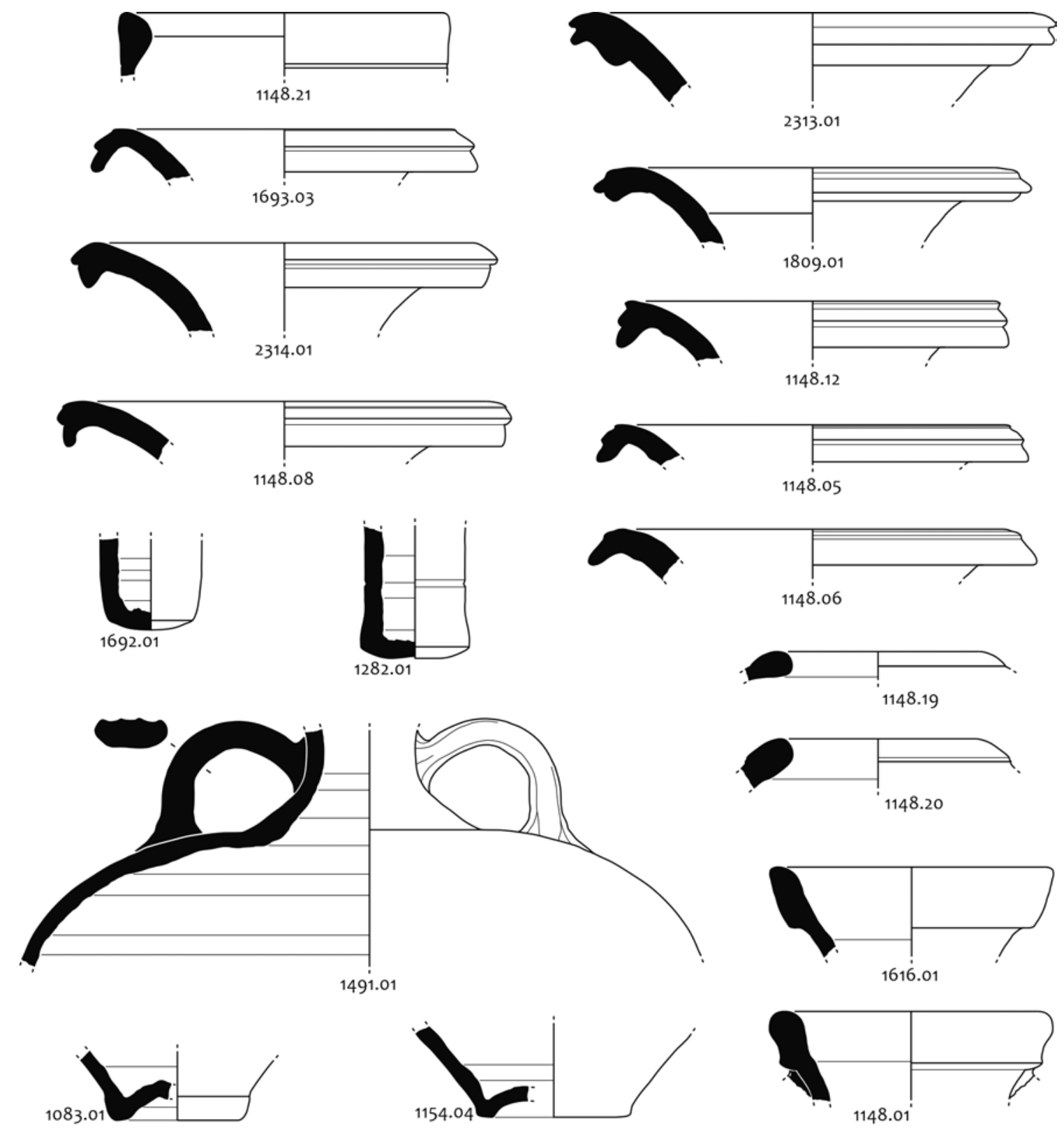

FIG. 8 Pátio José Sequeira. Ulterior, costa meridional: T-9.1.1.1. (1148.21), T-7.4.3.3. (1693.03, 1282.01, 1692.01, 2313.01, 1809.01, 2314.01, 1148.08, 1148.12, 1148.05, 1148.06). Ulterior, Vale do Tejo/Sado:Tipo 6 (1148.19, 1148.20). Ulterior, Vale do Guadalquivir: Ovóide 4 (1616.01). Lusitânia: Lusitana Antiga (1148.01), Lusitana 3 (1491.01, 1083.01, 1154.04).

\subsection{O conjunto anfórico do Largo de Santa Cruz do Castelo}

O conjunto de ânforas exumado durante a escavação do Largo de Santa Cruz do Castelo é constituído por um Número Mínimo de 120 Indivíduos, calculado a partir de um total de 287 fragmentos classificáveis, entre os quais 95 bordos, 46 fundos, 144 asas e duas paredes, uma das quais com vestígios de pez (Fig. 9). Maioritariamente enquadráveis no período Republicano $(92,5 \%)$, estão presentes 16 tipos distintos, procedentes de sete regiões produtoras.
A amostra republicana (113 NMI) constitui-se como um dos maiores conjuntos anfóricos de Lisboa dessa época, podendo-se considerar uma amostra de "fiabilidade suficiente" (Molina Vidal 1997). Em termos gerais, apresenta um perfil que se enquadra sobretudo na fase mais antiga da presença romana em Olisipo, sobressaindo maioritariamente as ânforas de tipo Greco-Itálico e as produções comercializadas desde o século II a.C., estendendo-se pela centúria seguinte; e, de forma minoritária, os envases cujo fabrico e difusão se processa a partir do segundo quartel ou de meados 
do século I a.C., nomeadamente as produções ovóides da Ulterior.

$\mathrm{Na}$ análise à origem dos contentores (Fig. 10), observa-se a preponderância das produções da costa tirrénica da Península Itálica, significando $66,37 \%$ dos materiais republicanos, unicamente representados pelas Greco-Itálicas (20,35\%) e Dressel 1 (34,51\%), com o predomínio desta última (52\% dos envases tirrénicos), e uma importante percentagem de indivíduos indistintamente classificados como Greco-Itálicas/Dressel 1 (11,5\%). Uma tão elevada percentagem das produções desta região na amostra deste sítio deverá relacionar-se directamente com o perfil antigo da mesma, característico da área da antiga Alcáçova Islâmica (Pimenta 2005), não se observando, todavia, situação similar no quadro global da cidade para a fase republicana

FIG. 9 Quantificação global das ânforas do Largo de Santa Cruz do Castelo.

\begin{tabular}{|c|c|c|c|c|c|c|c|c|}
\hline PROVENIÊNCIA & TIPO & TF & $\% \mathrm{TF}$ & NMI & $\% \mathrm{NMI}$ & $\begin{array}{c}\% \text { NMI } \\
\text { REGIÄO }\end{array}$ & $\begin{array}{c}\text { \% NMI } \\
\text { PROVÍNCIA }\end{array}$ & $\begin{array}{c}\% \text { NMI } \\
\text { EXTRAPROV. }\end{array}$ \\
\hline \multirow{3}{*}{ Lusitânia, Tejo/Sado } & Lusitana 3 & 1 & $0,35 \%$ & 1 & $0,83 \%$ & $50 \%$ & $50 \%$ & \\
\hline & Indeterminado & 1 & $0,35 \%$ & 1 & $0,83 \%$ & $50 \%$ & $50 \%$ & \\
\hline & Total & 2 & $0,7 \%$ & 2 & $1,7 \%$ & $100 \%$ & $100 \%$ & \\
\hline \multirow{2}{*}{$\begin{array}{l}\text { Bética, Vale do } \\
\text { Guadalquivir }\end{array}$} & Dressel 20 (Nero-Vespasiano) & 1 & $0,35 \%$ & 1 & $0,83 \%$ & $100 \%$ & $100 \%$ & $0,85 \%$ \\
\hline & Total & 1 & $0,35 \%$ & 1 & $0,83 \%$ & $100 \%$ & $100 \%$ & $0,85 \%$ \\
\hline \multirow{8}{*}{$\begin{array}{l}\text { Hispânia Ulterior, } \\
\text { costa meridional }\end{array}$} & Dressel 1 & 1 & $0,35 \%$ & 1 & $0,83 \%$ & $3,57 \%$ & $3,33 \%$ & $0,85 \%$ \\
\hline & Greco-Itálica/Dressel 1 & 7 & $2,44 \%$ & 2 & $1,67 \%$ & $7,14 \%$ & $6,67 \%$ & $1,71 \%$ \\
\hline & $\mathrm{T}-7.4 .3 .3$. & 35 & $12,2 \%$ & 19 & $15,8 \%$ & $67,86 \%$ & $63,33 \%$ & $16,24 \%$ \\
\hline & T-9.1.1.1. & 3 & $1,05 \%$ & 3 & $2,5 \%$ & $10,71 \%$ & $10 \%$ & $2,59 \%$ \\
\hline & Classe 67/Ovóide 1 & 1 & $0,35 \%$ & 1 & $0,83 \%$ & $3,57 \%$ & $3,33 \%$ & $0,85 \%$ \\
\hline & Ovóide 5 & 1 & $0,35 \%$ & 1 & $0,83 \%$ & $3,57 \%$ & $3,33 \%$ & $0,85 \%$ \\
\hline & Indeterminado & 1 & $0,35 \%$ & 1 & $0,83 \%$ & $100 \%$ & $100 \%$ & $0,85 \%$ \\
\hline & Total & 49 & $16,72 \%$ & 28 & $23,33 \%$ & $96 \%$ & & $23,95 \%$ \\
\hline \multirow{3}{*}{$\begin{array}{l}\text { Hispânia Ulterior, } \\
\text { Vale do Guadalquivir }\end{array}$} & T-7.4.3.3. & 1 & $0,35 \%$ & 1 & $0,83 \%$ & $50 \%$ & $3,33 \%$ & $0,85 \%$ \\
\hline & Ovóide 5 & 1 & $0,35 \%$ & 1 & $0,83 \%$ & $50 \%$ & $3,33 \%$ & $0,85 \%$ \\
\hline & Total & 2 & $0,7 \%$ & 2 & $1,67 \%$ & $100 \%$ & $197 \%$ & $1,71 \%$ \\
\hline \multirow{5}{*}{$\begin{array}{l}\text { Península Itálica, } \\
\text { costa tirrénica }\end{array}$} & Greco-Itálica & 26 & $9,06 \%$ & 23 & $19,17 \%$ & $30,26 \%$ & $27,71 \%$ & $19,66 \%$ \\
\hline & Dressel 1 & 41 & $14,29 \%$ & 39 & $32,5 \%$ & $51,3 \%$ & $46,99 \%$ & $33,33 \%$ \\
\hline & Greco-Itálica/Dressel 1 & 149 & $51,92 \%$ & 13 & $10,83 \%$ & $17,11 \%$ & $15,66 \%$ & $11,11 \%$ \\
\hline & Dressel 2-4 & 1 & $0,35 \%$ & 1 & $0,83 \%$ & $1,32 \%$ & $1,2 \%$ & $0,85 \%$ \\
\hline & Total & 217 & $75,61 \%$ & 76 & $63,33 \%$ & $100 \%$ & & $64,96 \%$ \\
\hline \multirow{4}{*}{$\begin{array}{l}\text { Península Itálica, } \\
\text { costa adriática }\end{array}$} & Greco-Itálica & 8 & $2,79 \%$ & 5 & $4,17 \%$ & $71,43 \%$ & $6,02 \%$ & $4,27 \%$ \\
\hline & Lamboglia 2 & 2 & $0,7 \%$ & 1 & $0,83 \%$ & $14,29 \%$ & $1,2 \%$ & $0,85 \%$ \\
\hline & Brindisi & 1 & $0,35 \%$ & 1 & $0,83 \%$ & $14,29 \%$ & $1,2 \%$ & $0,85 \%$ \\
\hline & Total & 11 & $3,83 \%$ & 7 & $5,83 \%$ & $100 \%$ & $100 \%$ & $5,98 \%$ \\
\hline \multirow{2}{*}{ Norte de África } & Africana Antiga & 2 & $0,7 \%$ & 2 & $1,67 \%$ & $100 \%$ & $100 \%$ & $1,71 \%$ \\
\hline & Total & 2 & $0,7 \%$ & 2 & $1,67 \%$ & $100 \%$ & $100 \%$ & $1,71 \%$ \\
\hline \multirow{2}{*}{ Mediterrâneo Oriental } & Cretense 4/Dressel 43 & 1 & $0,35 \%$ & 1 & $0,83 \%$ & $100 \%$ & $100 \%$ & $0,85 \%$ \\
\hline & Total & 1 & $0,35 \%$ & 1 & $0,83 \%$ & $100 \%$ & $100 \%$ & $0,85 \%$ \\
\hline \multirow{2}{*}{ Indeterminada } & Indeterminado & 2 & $0,7 \%$ & 1 & $0,83 \%$ & $100 \%$ & $100 \%$ & \\
\hline & Total & 2 & $0,7 \%$ & 1 & $0,83 \%$ & $100 \%$ & $100 \%$ & \\
\hline TOTAL & & 287 & $100 \%$ & 120 & $100 \%$ & & & $100 \%$ \\
\hline
\end{tabular}


(49,39\%), onde as produções da segunda metade do século I a.C. adquirem um peso mais significativo (Filipe 2019).

Embora as variantes de Dressel 1 correspondam maioritariamente às chamadas Dressel $1 \mathrm{~A}$ e Dressel 1 de transição, dever-se-á sublinhar a presença relativamente significativa das designadas Dressel $1 \mathrm{C}$ (Figs. 12-14), até agora escassamente documentadas no Castelo de São Jorge. Em relação às Greco-Itálicas, embora uma parte substantiva se enquadre formalmente no tipo de perfis típico da fase final da sua produção e de transição para a Dressel 1, registaram-se alguns exemplares evidenciando características de modelos mais antigos, ostentando bordos com menor inclinação externa, de que os melhores exemplos serão as peças n. ${ }^{\circ} 240$ e 252 para as produções adriáticas e 107 para as tirrénicas (Fig. 12).

Já as ânforas de fabrico adriático adquirem um carácter claramente minoritário $(6,19 \%)$, ainda que se superiorizem às do Norte de África e do Vale do
Guadalquivir. Daquelas, destacam-se as Greco-Itálicas $(4,42 \%)$ com cinco indivíduos, estando ainda presentes as Lamboglia 2 e as ânforas brindisinas com um indivíduo cada, em ambos casos, representadas apenas por fragmentos de fundo e asa.

A costa meridional da Hispânia Ulterior constitui-se como a segunda região produtora mais importante na amostra deste sítio (23,89\%), sendo representada principalmente pelo abastecimento de produtos piscícolas transportados nas T-7.4.3.3. (70,37\% dos envases dessa zona) e, em menor escala, nas T-9.1.1.1. $(11,11 \%)$, Dressel 1 (1 NMI =3,7\%) e, eventualmente, nas Greco-Itálicas. Concretamente em relação a este último tipo, refira-se que não foi identificado qualquer bordo com fabrico atribuível ao litoral Sul da Ulterior nos dois conjuntos aqui em apreço, contrariamente ao que se verifica na publicação dos dados do Castelo de São Jorge, onde aquelas atingem percentagens na ordem dos 6\% (Pimenta 2005: Quadro 12). Em sentido inverso, a proporção de Greco-Itálicas da costa

FIG. 10 Quantificação das ânforas republicanas do Largo de Santa Cruz do Castelo.

\begin{tabular}{|c|c|c|c|c|c|c|c|c|}
\hline PROVENIÊNCIA & TIPO & TF & $\% \mathrm{TF}$ & NMI & $\%$ NMI & $\begin{array}{c}\% \text { NMI } \\
\text { REGIÃO }\end{array}$ & $\begin{array}{c}\% \text { NMI } \\
\text { PROVÍNCIA }\end{array}$ & $\begin{array}{c}\% \text { NMI } \\
\text { EXTRAPROV. }\end{array}$ \\
\hline \multirow{7}{*}{$\begin{array}{l}\text { Hispânia Ulterior, } \\
\text { costa meridional }\end{array}$} & Dressel 1 & 1 & $0,36 \%$ & 1 & $0,88 \%$ & $3,7 \%$ & $3,45 \%$ & $0,88 \%$ \\
\hline & Greco-Itálica/Dressel 1 & 7 & $2,51 \%$ & 2 & $1,77 \%$ & $7,41 \%$ & $6,9 \%$ & $1,74 \%$ \\
\hline & T-7.4.3.3. & 35 & $12,54 \%$ & 19 & $16,81 \%$ & $70,37 \%$ & $65,52 \%$ & $16,81 \%$ \\
\hline & T-9.1.1.1. & 3 & $1,08 \%$ & 3 & $2,65 \%$ & $11,11 \%$ & $10,34 \%$ & $2,65 \%$ \\
\hline & Classe 67/Ovóide 1 & 1 & $0,36 \%$ & 1 & $0,88 \%$ & $3,7 \%$ & $3,45 \%$ & $0,88 \%$ \\
\hline & Ovóide 5 & 1 & $0,36 \%$ & 1 & $0,88 \%$ & $3,7 \%$ & $3,45 \%$ & $0,88 \%$ \\
\hline & Total & 48 & $17,2 \%$ & 27 & $23,89 \%$ & $100 \%$ & & $23,86 \%$ \\
\hline \multirow{3}{*}{$\begin{array}{l}\text { Hispânia Ulterior, } \\
\text { Vale do Guadalquivir }\end{array}$} & T-7.4.3.3. & 1 & $0,36 \%$ & 1 & $0,88 \%$ & $50 \%$ & $3,45 \%$ & $0,88 \%$ \\
\hline & Ovóide 5 & 1 & $0,36 \%$ & 1 & $0,88 \%$ & $50 \%$ & $3,45 \%$ & $0,88 \%$ \\
\hline & Total & 2 & $0,72 \%$ & 2 & $1,77 \%$ & $100 \%$ & $100 \%$ & $1,77 \%$ \\
\hline \multirow{4}{*}{$\begin{array}{l}\text { Península Itálica, } \\
\text { costa tirrénica }\end{array}$} & Greco-Itálica & 26 & $9,32 \%$ & 23 & $20,35 \%$ & $30,7 \%$ & $28,05 \%$ & $20,35 \%$ \\
\hline & Dressel 1 & 41 & $14,7 \%$ & 39 & $34,51 \%$ & $52,0 \%$ & $47,56 \%$ & $34,51 \%$ \\
\hline & Greco-Itálica/Dressel 1 & 149 & $53,41 \%$ & 13 & $11,5 \%$ & $17 \%$ & $16 \%$ & $11,5 \%$ \\
\hline & Total & 216 & $77,42 \%$ & 75 & $66,37 \%$ & $100 \%$ & & $66,37 \%$ \\
\hline \multirow{4}{*}{$\begin{array}{l}\text { Península Itálica, } \\
\text { costa adriática }\end{array}$} & Greco-Itálica & 8 & $2,87 \%$ & 5 & $4,42 \%$ & $71,43 \%$ & $6,10 \%$ & $4,42 \%$ \\
\hline & Lamboglia 2 & 2 & $0,72 \%$ & 1 & $0,88 \%$ & $14,29 \%$ & $1,22 \%$ & $0,88 \%$ \\
\hline & Brindisi & 1 & $0,36 \%$ & 1 & $0,88 \%$ & $14,29 \%$ & $1,22 \%$ & $0,88 \%$ \\
\hline & Total & 11 & $3,94 \%$ & 7 & $6,19 \%$ & $100 \%$ & $100 \%$ & $6,19 \%$ \\
\hline \multirow{2}{*}{ Norte de África } & Africana Antiga & 2 & $0,72 \%$ & 2 & $1,77 \%$ & $100 \%$ & $100 \%$ & $1,77 \%$ \\
\hline & Total & 2 & $0,72 \%$ & 2 & $1,77 \%$ & $100 \%$ & $100 \%$ & $1,77 \%$ \\
\hline TOTAL & & 279 & $100 \%$ & 113 & $100 \%$ & & & $100 \%$ \\
\hline
\end{tabular}


FIG. 11 Quantificação por conteúdo das ânforas republicanas do Largo de Santa Cruz do Castelo.

\begin{tabular}{|c|c|c|c|c|c|c|c|}
\hline CONTEÚDO & PROVENIÊNCIA & TIPO & NMI & $\%$ NMI & $\begin{array}{c}\text { \% NMI } \\
\text { CONTEÚDO } \\
\text { REGIĀO }\end{array}$ & $\begin{array}{c}\% \text { NMI } \\
\text { CONTEÚDO } \\
\text { PROVÍNCIA }\end{array}$ & $\begin{array}{c}\text { \% NMI } \\
\text { CONTEÚDO }\end{array}$ \\
\hline \multirow{8}{*}{$\begin{array}{l}\text { Preparados } \\
\text { piscícolas }\end{array}$} & \multirow{5}{*}{$\begin{array}{l}\text { Hispânia Ulterior, } \\
\text { costa meridional }\end{array}$} & Dressel 1 & 1 & $0,88 \%$ & $4 \%$ & $3,85 \%$ & $3,85 \%$ \\
\hline & & Greco-Itálica/Dressel 1 & 2 & $1,77 \%$ & $8 \%$ & $7,69 \%$ & $7,69 \%$ \\
\hline & & T-7.4.3.3. & 19 & $16,81 \%$ & $76 \%$ & $73,08 \%$ & $73,08 \%$ \\
\hline & & T-9.1.1.1. & 3 & $2,65 \%$ & $12 \%$ & $11,54 \%$ & $11,54 \%$ \\
\hline & & Total & 25 & $22,12 \%$ & $100 \%$ & & $96,15 \%$ \\
\hline & \multirow{2}{*}{$\begin{array}{l}\text { Hispânia Ulterior, } \\
\text { Vale do Guadalquivir }\end{array}$} & T-7.4.3.3. & 1 & $0,88 \%$ & $100 \%$ & $3,85 \%$ & $3,85 \%$ \\
\hline & & Total & 1 & $0,88 \%$ & $100 \%$ & $100 \%$ & $3,85 \%$ \\
\hline & TOTAL & & 26 & $23,01 \%$ & & & $100 \%$ \\
\hline \multirow{8}{*}{$\begin{array}{l}\text { Vinho } \\
\text { e derivados }\end{array}$} & \multirow{4}{*}{$\begin{array}{l}\text { Península Itálica, } \\
\text { costa tirrénica }\end{array}$} & Greco-Itálica & 23 & $20,35 \%$ & $30,67 \%$ & $28,4 \%$ & $28,4 \%$ \\
\hline & & Dressel 1 & 39 & $34,51 \%$ & $52 \%$ & $48,15 \%$ & $48,15 \%$ \\
\hline & & Greco-Itálica/Dressel 1 & 13 & $11,5 \%$ & $17,33 \%$ & $16,05 \%$ & $16,05 \%$ \\
\hline & & Total & 75 & $66,37 \%$ & $100 \%$ & & $92,59 \%$ \\
\hline & \multirow{3}{*}{$\begin{array}{l}\text { Península Itálica, } \\
\text { costa adriática }\end{array}$} & Greco-Itálica & 5 & $4,42 \%$ & $83,33 \%$ & $6,17 \%$ & $6,17 \%$ \\
\hline & & Lamboglia 2 & 1 & $0,88 \%$ & $16,67 \%$ & $1,23 \%$ & $1,23 \%$ \\
\hline & & Total & 6 & $5,31 \%$ & $100 \%$ & $100 \%$ & $7,41 \%$ \\
\hline & TOTAL & & 81 & $71,68 \%$ & & & $100 \%$ \\
\hline \multirow{10}{*}{ Azeite } & \multirow{3}{*}{$\begin{array}{l}\text { Hispânia Ulterior, } \\
\text { costa meridional }\end{array}$} & Classe 67/Ovóide 1 & 1 & $0,88 \%$ & $50 \%$ & $33,33 \%$ & $16,67 \%$ \\
\hline & & Ovóide 5 & 1 & $0,88 \%$ & $50 \%$ & $33,33 \%$ & $16,67 \%$ \\
\hline & & Total & 2 & $1,77 \%$ & $100 \%$ & & $33,33 \%$ \\
\hline & \multirow{2}{*}{$\begin{array}{l}\text { Hispânia Ulterior, } \\
\text { Vale do Guadalquivir }\end{array}$} & Ovóide 5 & 1 & $0,88 \%$ & $100 \%$ & $33,33 \%$ & $16,67 \%$ \\
\hline & & Total & 1 & $0,88 \%$ & $100 \%$ & $100 \%$ & $16,67 \%$ \\
\hline & \multirow{2}{*}{$\begin{array}{l}\text { Península Itálica, } \\
\text { costa adriática }\end{array}$} & Brindisi & 1 & $0,88 \%$ & $100 \%$ & $100 \%$ & $16,67 \%$ \\
\hline & & Total & 1 & $0,88 \%$ & $100 \%$ & $100 \%$ & $16,67 \%$ \\
\hline & \multirow{2}{*}{ Norte de África } & Africana Antiga & 2 & $1,77 \%$ & $100 \%$ & $100 \%$ & $33,33 \%$ \\
\hline & & Total & 2 & $1,77 \%$ & $100 \%$ & $100 \%$ & $33,33 \%$ \\
\hline & \multicolumn{2}{|l|}{ TOTAL } & 6 & $5,31 \%$ & & & $100 \%$ \\
\hline TOTAL & & & 113 & $100 \%$ & & & \\
\hline
\end{tabular}

adriática é muito superior na amostra que aqui se analisa. No Largo de Santa Cruz do Castelo registaram-se, para além de algumas asas, dois fragmentos de fundo de fabrico atribuível àquela região costeira da Ulterior indistintamente classificados como Greco-Itálica/ Dressel 1, correspondendo aos únicos testemunhos da eventual presença dessas imitações hispânicas neste conjunto.

Para além das já referidas, completam o quadro das ânforas republicanas daquela região dois tipos de forma ovóide produzidas a partir do segundo quartel do século I a.C., a Classe 67/Ovóide 1 e a Ovóide 5 (Fig. 15), que merecem um apontamento especial.
A primeira, embora já conhecida em Lisboa (Pimenta 2005; 2007; Filipe 2015; 2019), surge aqui pela primeira vez com um fabrico da área costeira, o que, embora não seja surpreendente uma vez que já havia sido detectada em Scallabis (Arruda - Viegas - Bargão 2005), constitui-se como uma novidade na cidade. Em relação à Ovóide 5 é de realçar que este exemplar apresenta um fabrico claramente imputável à área costeira de Málaga, contrariamente à generalidade dos contentores deste tipo conhecidos e publicados no ocidente hispânico e inclusivamente aos documentados em Olisipo, todos eles atribuíveis ao Vale do Guadalquivir (Filipe 2019). 
As produções desta última região $(1,77 \%)$ estão representadas precisamente por um exemplar de Ovóide 5 e por um outro de tipo T-7.4.3.3., acerca do qual se poderá, em sentido inverso, referir o mesmo que se disse em relação à Ovóide 5 costeira. As T-7.4.3.3. de fabrico costeiro estão densamente documentadas em toda a fachada atlântica e particularmente em Lisboa. No entanto, as variantes desse tipo produzidas no Vale do Guadalquivir são raras e, até agora, desconhecidas em Olisipo, estando, contudo, já documentadas em Santarém (Almeida 2008).

Por fim, as produções norte-africanas, claramente minoritárias $(1,77 \%)$, marcam presença com as designadas Africana Antiga das quais se exumaram dois indivíduos (Fig. 15), estando ausentes as T-7.4.2.1./T-7.4.3.1.

Relativamente aos produtos comercializados durante a fase republicana, o panorama é nitidamente dominado pelo vinho $(71,68 \%)$, exclusivamente proveniente da Península Itálica, particularmente da costa tirrénica (92,59\% desse artigo) e em menor escala da adriática (7,41\%). A Dressel 1 representa 48,15\% da importação desse produto enquanto a Greco-Itálica significa $34,57 \%$, repartindo-se por $28,4 \%$ com origem na costa tirrénica e $6,17 \%$ na adriática. Tendo em consideração o curto lapso temporal em que aquele último tipo foi comercializado no extremo ocidental da Península Ibérica, que não terá sido muito superior a um decénio, não restarão dúvidas que nesses primeiros anos da presença romana no estuário do Tejo as Greco-Itálicas terão desempenhado o papel mais importante no abastecimento de vinho aos contingentes militares. Resta mencionar a presença minoritária de um outro contentor vinário produzido na costa adriática, a Lamboglia 2, cuja representação não ultrapassa os $0,88 \%$.

Os preparados piscícolas constituem-se como o segundo produto mais importado em contentores anfóricos $(23,01 \%)$, neste caso oriundos unicamente da costa meridional $(96,15 \%$ desse produto) e do Vale do Guadalquivir (3,85\%) na província hispânica da Ulterior. No âmbito dos contentores piscícolas, a supremacia da T-7.4.3.3. é absoluta (76,92\% no total: costa, 73,08\%; Guadalquivir, 3,85\%), algo que não foge muito dos valores habituais para esta fase no ocidente, já que este tipo é o grande representante do comércio dos produtos à base de peixe produzidos na região meridional da Ulterior. A T-9.1.1.1., ainda que minoritária, assume-se como o segundo tipo mais importante na comercialização daquele produto (11,54\%), embora a Dressel 1 (3,85\%) possa apresentar proporção idêntica se se considerar a possibilidade das peças indistintamente classificadas como Greco-Itálica/Dressel 1 $(7,69 \%)$ corresponderem efectivamente a envases do tipo Dressel 1.

O já mencionado perfil antigo da amostra estará directamente relacionado com a escassa importância do comércio de azeite verificável no conjunto (5,31\%) onde, ainda assim, 50\% desse produto terá chegado já a partir do segundo quartel do século I a.C. envasado em contentores ovóides da área meridional hispânica. A maior fatia das ânforas oleícolas do Largo de Santa Cruz é repartida pelas Classe 67/Ovóide 1 e Ovóide 5 da costa Sul da Ulterior (33,33\%) e pelas Africana Antiga (33,33\%) oriundas do Norte de África. O azeite adriático, representado pelas ânforas de Brindisi, significa apenas $16,67 \%$, à semelhança do procedente do Vale do Guadalquivir, envasado nas Ovóide 5.

Em termos gerais, o quadro de consumo evidenciado pela amostra do Largo de Santa Cruz enquadra-se no perfil característico da área da antiga Alcáçova (Pimenta 2005), afastando-se do que se verifica na vertente Sul, particularmente evidenciado pelo conjunto da Sé (Filipe 2019).

Embora de forma meramente vestigial, a identificação de contentores alto-imperiais neste local é particularmente interessante. Por um lado, a já mencionada escassez de materiais dessa época no espaço da Alcáçova sublinha a importância da sua identificação na intervenção do Largo de Santa Cruz do Castelo. A proximidade deste sítio relativamente ao Grupo Desportivo do Castelo (Filipe 2019), onde se registou a presença de uma estrutura dessa época, enfatiza ainda mais essa importância sugerindo, simultaneamente, uma relação directa com a utilização daquele edifício imperial de que se desconhece a funcionalidade, mas cujo carácter monumental terá levado os responsáveis pela intervenção a considerar a hipótese de se tratar de um edifício de carácter público (Silva 2012). Por outro lado, é interessante verificar que, com excepção de uma asa de Dressel 20 com marca de oleiro, os restantes contentores destinavam-se ao transporte de vinho: Lusitana 3, Dressel 2-4 itálica e Cretense 4/Dressel 43. Destes, talvez o último se possa considerar o mais interessante na medida em que a sua ocorrência em Lisboa apenas se encontra atestada na Rua dos Bacalhoeiros (Filipe 2019). 


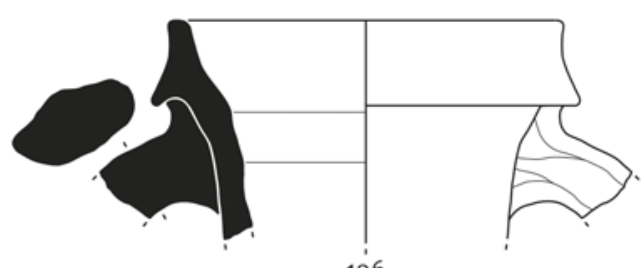

196
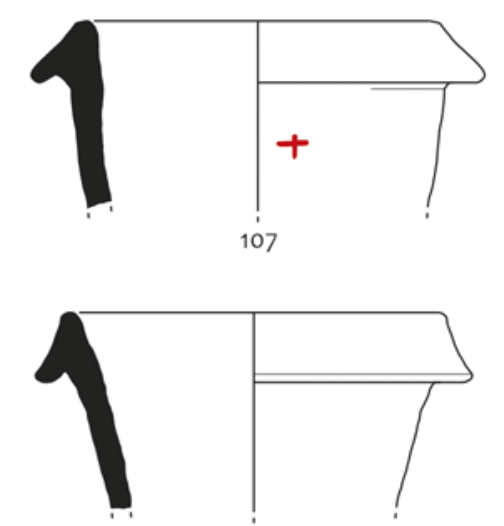

247

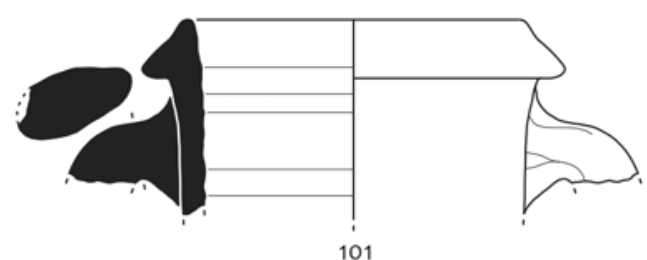

101

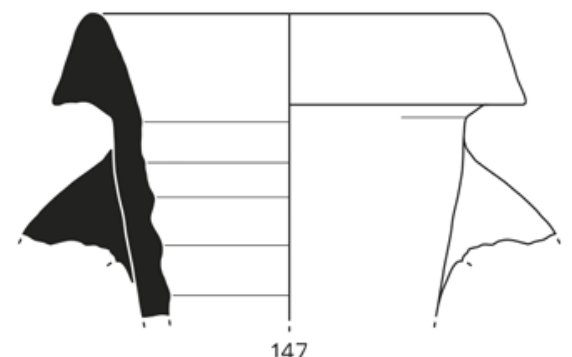

147
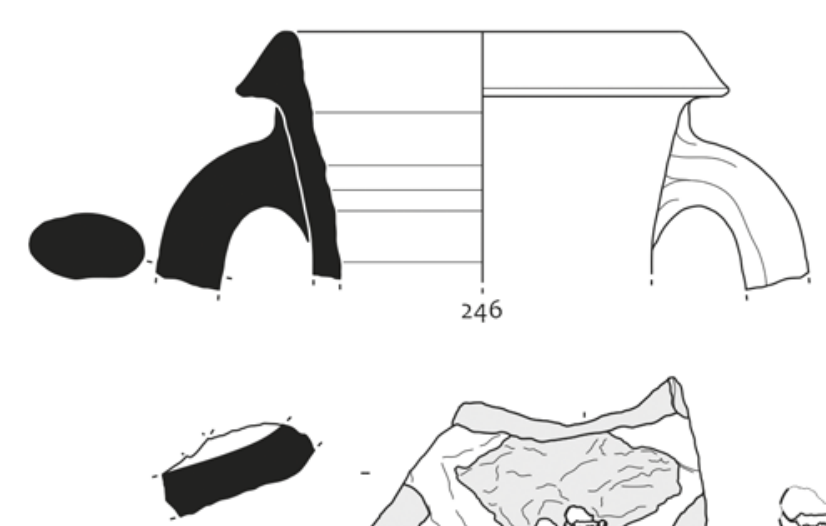
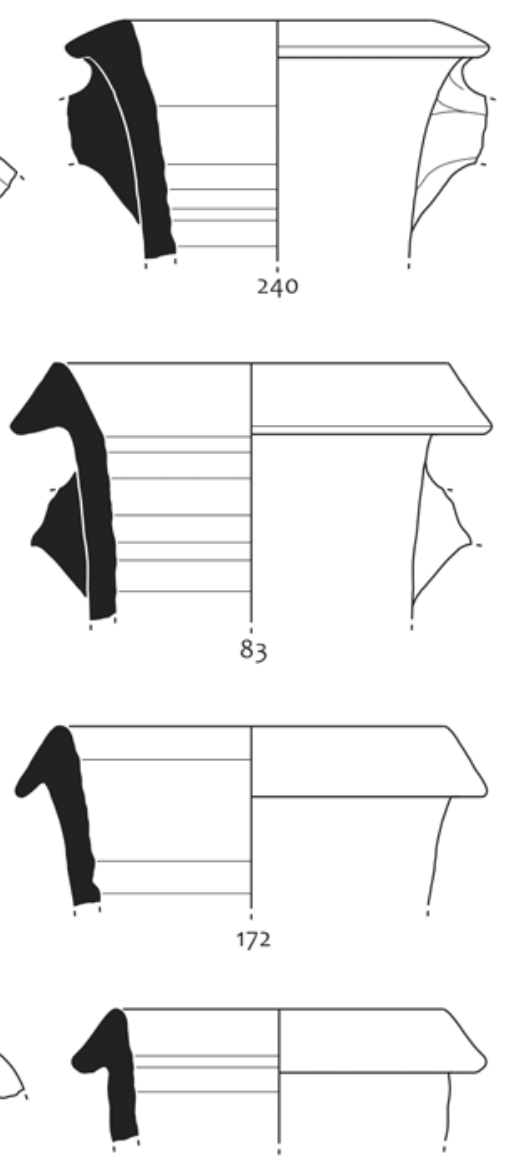

197

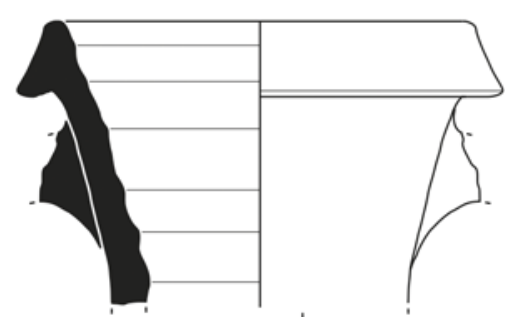

62

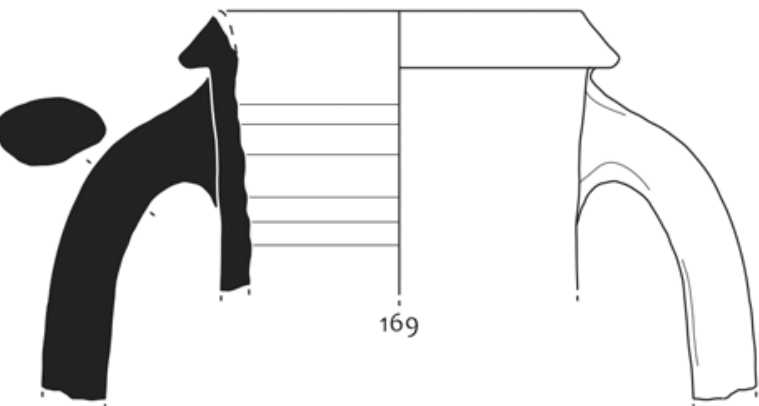

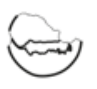
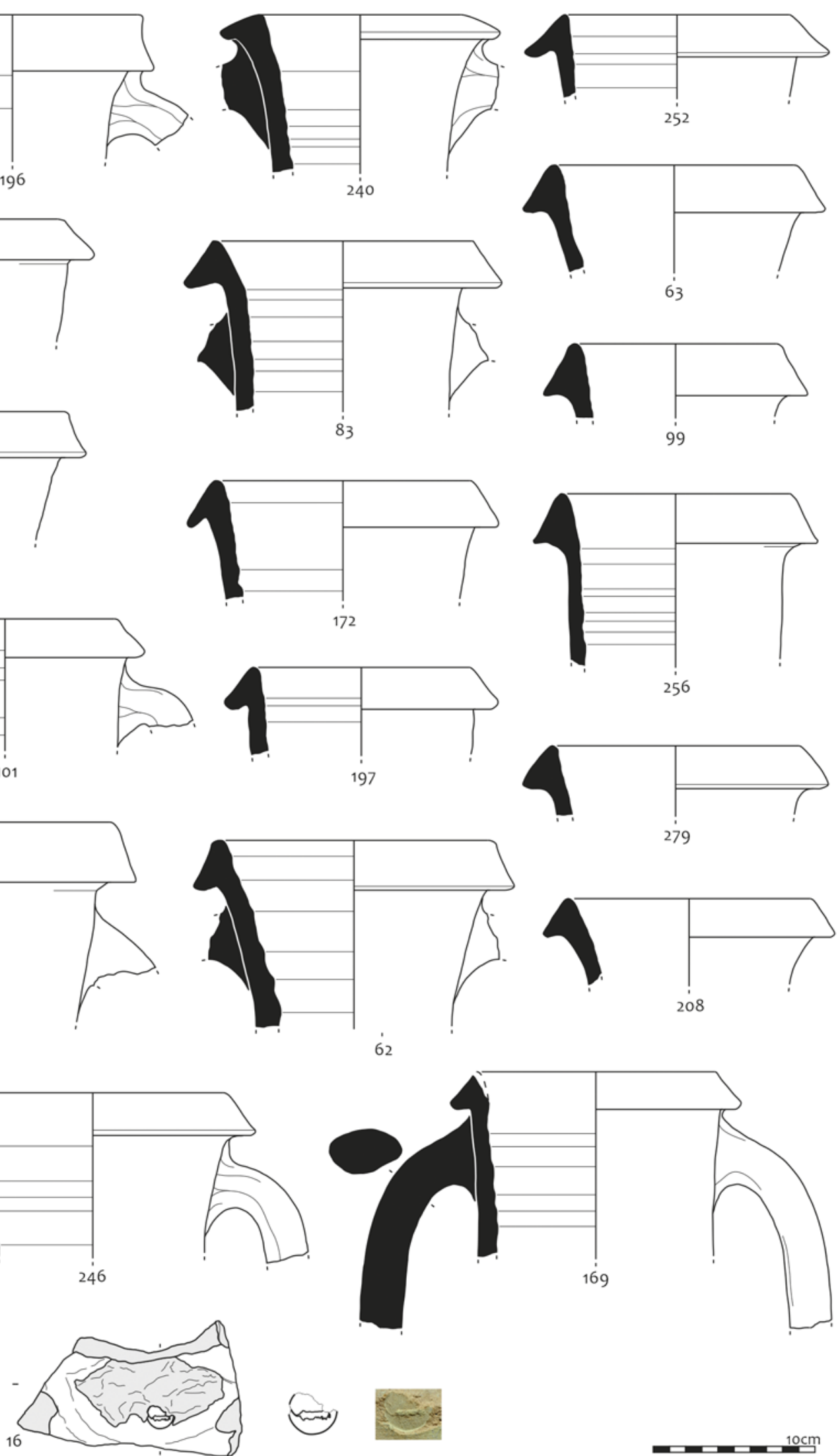

FIG. 12 Largo de Santa Cruz do Castelo. Península Itálica, costa adriática: Greco-Itálica (196, 240, 252, 279). Península Itálica, costa tirrénica: Greco-Itálica (as restantes). 

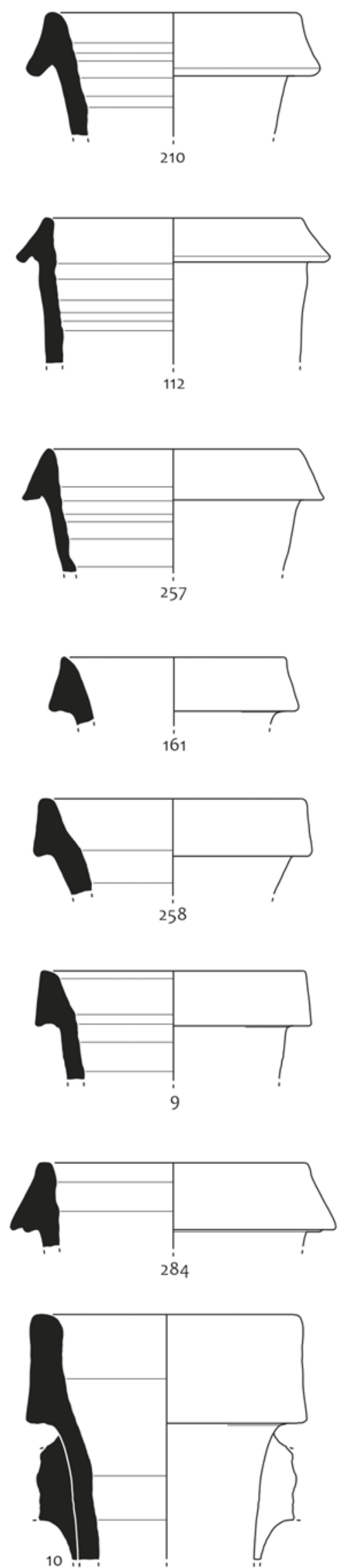
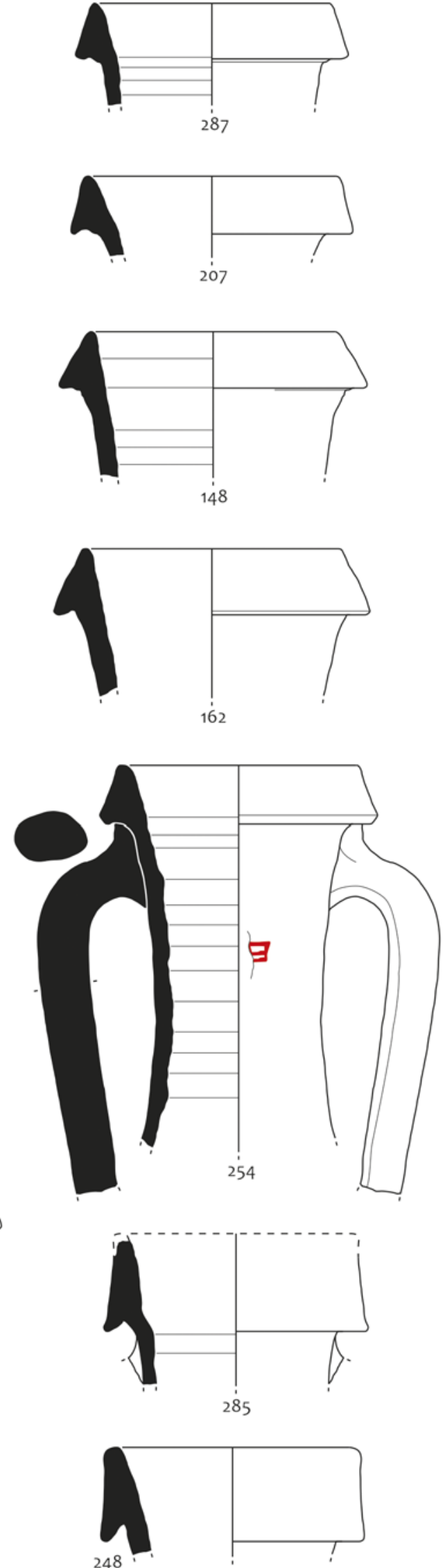
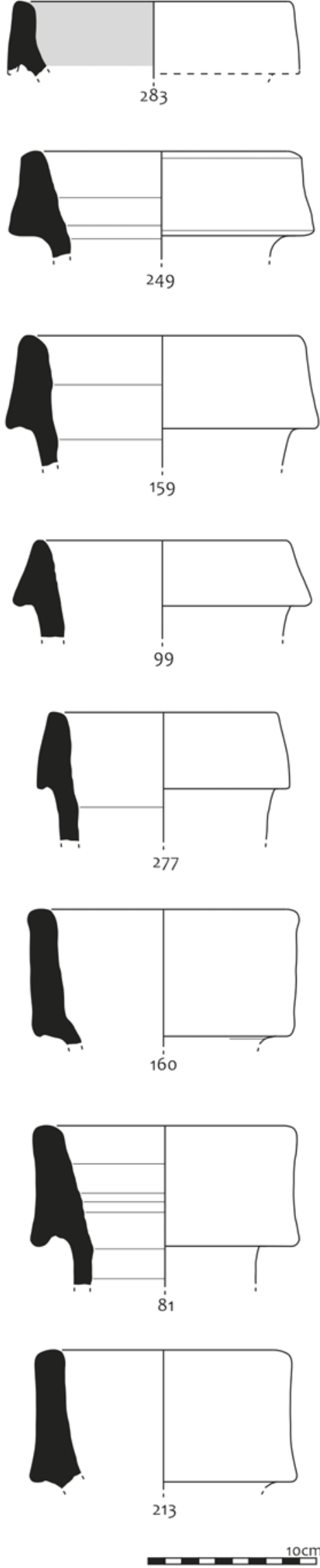

FIG. 13 Largo de Santa Cruz do Castelo. Península Itálica, costa tirrénica: Dressel 1. 

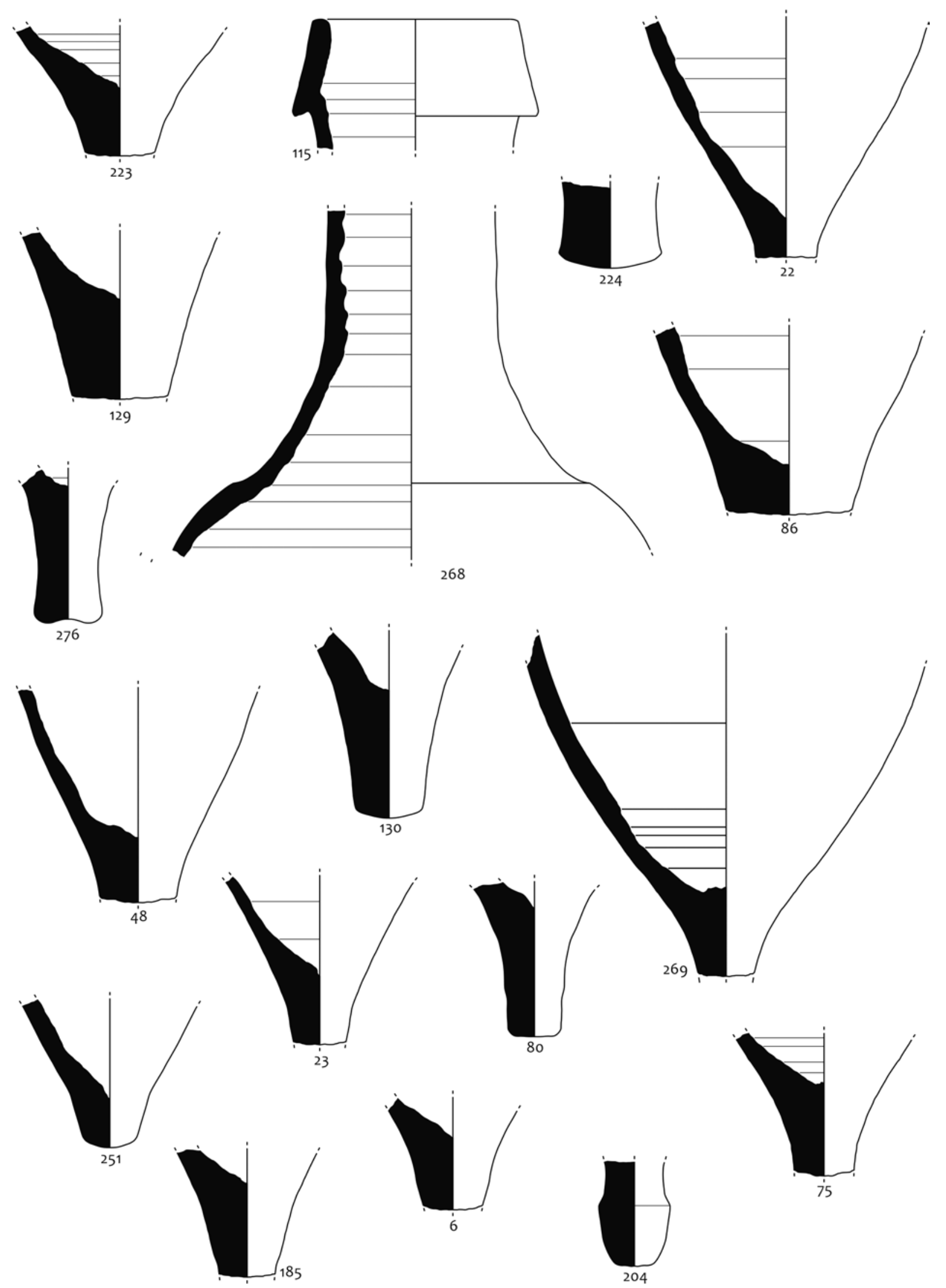

FIG. 14 Largo de Santa Cruz do Castelo. Península Itálica, costa tirrénica: Greco-Itálica? (204), Dressel 1 (115), Greco-Itálicas/Dressel 1 (as restantes). 

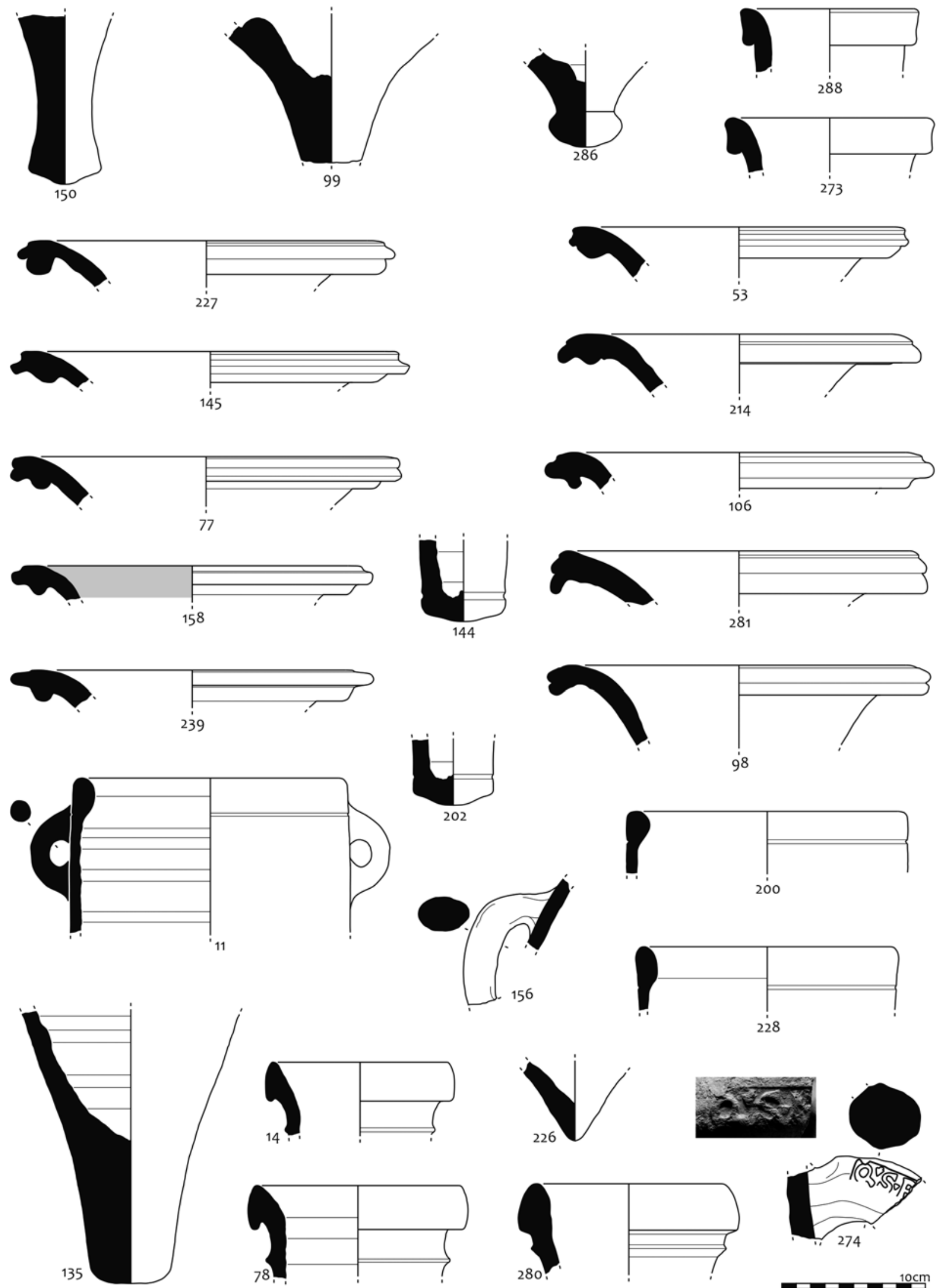

FIG. 15 Largo de Santa Cruz do Castelo. Península Itálica, costa tirrénica: Dressel 2-4 (150). Península Itálica, costa adriática: Lamboglia 2? (99), Ânfora de Brindisi (286). Norte de África: Africana Antiga (288, 273). Ulterior, costa meridional: T-7.4.3.3. (227, 53, 145, 77, 156, 158, 239, 144, 202, 214, 106, 281, 98), T-9.1.1.1. (200, 228, 11). Greco-Itálica/Dressel 1 (135), Classe 67 (280), Ovóide 5 (14). Ulterior/Bética, Vale do Guadalquivir: Ovóide 5 (78), Dressel 20 Nero-Vespasiano (274). Mediterrâneo oriental: Cretense 4 (226). 


\section{EPIGRAFIA ANFÓRICA}

\subsection{Marcas}

Nos conjuntos anfóricos aqui em apreço foram identificadas três marcas de oleiro, correspondendo duas delas a produções republicanas, da ilha de Cos e da Península Itálica, e a outra a uma produção Alto-Imperial do Vale do Guadalquivir.

Relativamente à primeira, uma marca com caracteres gregos aposta sobre a asa de um ânfora republicana de tipo Dressel 4 de Cos - [---]APA $\boldsymbol{\Sigma} \&[---] \mathrm{KPA} \Sigma$-, foi exumada num contexto possivelmente enquadrável na segunda metade do século I a.C. (Fig. 7) no Pátio José Pedreira. Fragmentada na sua parte inicial, são visíveis as três últimas letras da inscrição e parte de uma outra, que poderá corresponder a um A ou K, não sendo certo se existiria ou não outra letra antes desta última. Tanto na bibliografia consultada como na base de dados Amphoralex (www.amphoralex.org) não foram encontrados paralelos exactos. Existe, contudo, referência a uma marca de Dressel 4 de Cos identificada na área meridional do Levante (actuais Israel e Palestina) cuja inscrição - APA $\Sigma$ ([+clava] - é coincidente, embora no caso do exemplar do Castelo não se observe a presença da clava. Numa consulta à lista dos nomes gregos no índice de Fraser e Mathews (1987) e à correspondente base de dados (www.lgpn.ox.ac.uk), é possível verificar a existência de vários nomes que terminam ou que contêm APA $\Sigma$ ou KPA $\Sigma$, pelo que, enquanto se não conhecerem exemplares completos, terão que se assumir várias hipóteses para a inscrição desta marca.

A identificação desta peça constitui-se como uma novidade no ocidente hispânico (a que se deverá acrescentar o acima mencionado exemplar de Mértola, em vias de publicação), ampliando o repertório anfórico das importações republicanas no Vale do Tejo, onde estavam já atestados os contentores ródios provenientes da mesma região do Mediterrâneo e que se deverão inserir nos abastecimentos aos contingentes militares presentes no Vale do Tejo durante a República (Filipe 2019).

O outro exemplar republicano foi exumado em contexto de Época Medieval no Largo de Santa Cruz do Castelo, sendo provável que corresponda a uma ânfora de tipo Greco-Itálico ou, com menor probabilidade, Dressel 1. Trata-se de uma marca aposta no arranque inferior da asa, com cartela aparentemente circular, incompleta e com contornos mal definidos, parecendo corresponder à representação de um símbolo ou de uma figura zoomórfica. A fractura não permite perceber se teria ou não inscrição.

Em Lisboa são já conhecidas algumas marcas com cartela circular sobre Greco-Itálicas, embora situadas no topo da asa, três das quais representando um busto de perfil com a face virada à direita e, a outra, um elefante, todas com a inscrição LANICI (Pimenta 2005; 2014; Fabião et al. 2016). A marca do Largo de Santa Cruz do Castelo difere na representação e na aparente ausência de inscrição, sendo ainda ligeiramente maior, mas parece enquadrar-se no mesmo tipo de estampiIha e, certamente, na mesma tipologia e âmbito cronológico e de produção.

Não se logrou identificar qualquer paralelo. Refira-se, porém, a presença de marcas idênticas - com cartela circular e representação de símbolos de difícil caracterização - em Mont Beuvray, França, embora neste caso sobre Dressel 1 e localizadas no ombro e no bordo (CEIPAC 21021, 21023, 21024).

Por fim, foi identificada no Largo de Santa Cruz do Castelo a marca de oleiro Q.S.P sobre asa de Dressel 20 da fase Nero-Vespasiano, proveniente da Casa del Encinarejo Bajo (Fig. 15). Exumada num aterro de Época Medieval, esta marca era até aqui desconhecida no ocidente Peninsular. A parte inferior das duas primeiras letras está mal conservada, encontrando-se fracturada um pouco antes do limite do $\mathrm{P}, \mathrm{O}$ que não permite apurar se se está na presença da variante QSP((ramus palmae)), ainda que esta pareça ser menos comum. Conheceu uma ampla difusão nos mercados civis e militares da metade ocidental do Império, onde está particularmente bem atestada, ocorrendo ainda em Alexandria e em alguns naufrágios no Mediterrâneo (CEIPAC 6523; Will 1983; Remesal Rodríguez 1986; Márquez Villora - Molina Vidal 2005; Berni Millet 2017).

\subsection{Tituli picti}

Foram registados cinco tituli picti, integralmente inscritos no colo de ânforas republicanas da costa tirrénica da Península Itálica do tipo Dressel 1 e Greco-Itálica, efectuados com tinta vermelha e compostos por uma ou mais letras ou símbolo/s. Ainda que pouco numerosos e em parte incompletos, correspondem ao 
maior conjunto deste tipo de inscrições proveniente de Lisboa, onde até ao momento se encontram fracamente documentadas (Filipe 2015; 2019).

A sua interpretação é dificultada por diversos factores. Desde logo, pelo facto de algumas delas se situarem junto à fractura da peça, não permitindo perceber se existiriam outros signos. Em outros casos, não é totalmente claro se a inscrição seria originariamente constituída apenas pela letra ou símbolo actualmente visível ou se este corresponde simplesmente ao único elemento que se preservou. Enfim, para além destes aspectos, haverá ainda que ter em conta que a leitura das inscrições preservadas não é totalmente clara.

No caso das peças do Pátio José Pereira parece relativamente pacífico tratar-se de um B no exemplar n. ${ }^{2} 2444.02$ e de um $S$ no 2444.15, estando as inscrições, em ambos casos, aparentemente completas (Fig. 5). Já o titulus n. ${ }^{\circ} 1168.01$, onde parece estar representado um E deitado, poderia conter outras letras, números ou símbolos, já que a peça se encontra fracturada justamente junto ao limite da letra (Fig. 7).

No caso do exemplar n. ${ }^{\circ} 254$ do Largo de Santa Cruz do Castelo, a fractura da peça seccionou parte da letra, podendo neste caso corresponder a um B ou a um E invertido (Fig. 13). Já o titulus do exemplar n. ${ }^{\circ} 107$, parece estar completo, surgindo isolado e estando representado o símbolo + ou a letra X (Fig.12).

Os tituli picti sobre ânforas republicanas tirrénicas compostos por apenas uma ou duas letras são relativamente frequentes e normalmente de difícil interpretação. Alguns autores sugerem a sua associação a um sistema de contabilização (Benquet - Grizeaud 2009: 657). A este respeito veja-se, a título de exemplo, as inscrições identificadas em Toulouse, onde tanto se registaram tituli picti com apenas uma letra como outros mais extensos (idem: fig. 5 e 15.2); ou a do Museo di Fiesole, Itália, onde, numa inscrição com três linhas em que é indicada uma data consular, a primeira é constituída apenas pela letra B (Manacorda 1989: 447 e figs. 4 e 5). Refira-se também o titulus do Teatro Romano de Lisboa, composto apenas pela letra N (Filipe 2015).

Este tipo de inscrições foi recentemente sistematizado por J. Torres Costa, E. Marlière e C. de Nicolás (2014), tendo estes autores colocado em evidência o carácter abreviado da informação constante nestes tituli picti, que podiam incluir a denominação do vinho envasado, o número de anos do seu envelhecimento e, embora mais raramente, um qualificativo sobre esse vinho (por ex., falerno) (García Fernández et al. 2020).

\subsection{Grafitos}

Nos conjuntos em apreço foram reconhecidos apenas dois grafitos, ambos provenientes do Pátio José Pedreira. Trata-se em ambos casos de inscrições realizadas num momento posterior à cozedura da peça (post cocturam).

No caso do exemplar 2444.01 (Fig. 6), o grafito foi efectuado no ombro de uma Dressel 1 da costa tirrénica da Península Itálica, podendo ler-se [---]VIS(I?)[---]. Sendo certo que se trata de um grafito alfabético, o facto de se encontrar truncado na parte inicial e na parte final torna a sua interpretação extremamente problemática.

Igualmente complexa é a interpretação do grafito registado na peça 1766.01, efectuado sobre a pança de uma ânfora itálica e que também se encontra incompleto (Fig. 7). São visíveis três traços verticais paralelos, cruzados por outros dois dispostos obliquamente. Não parecendo constituir uma inscrição alfabética ou numeral, deverá muito provavelmente corresponder a um símbolo.

\section{CONSIDERAÇÕES FINAIS}

A antiga Alcáçova Islâmica de Lisboa constitui-se como um espaço singular no âmbito da cidade romana de Olisipo. O tipo de ocupação que aquela área conheceu durante os vários séculos do domínio romano parece ter sido sempre distinto do que se observou no restante espaço da cidade. Se esta distinção é particularmente visível no volume e no perfil de importação de ânforas nos níveis republicanos, não o é menos na escassez e mesmo ausência de contextos arqueológicos enquadráveis na lata diacronia que se estende do segundo quartel/meados do século I a.C. até ao final da presença romana no ocidente.

Embora introduzam novas e importantes nuances, que vêm complementar o panorama anteriormente traçado, os conjuntos anfóricos do Largo de Santa Cruz do Castelo e do Pátio José Pedreira confirmam as principais tendências que se haviam já documentado no quadro de consumo daquela zona da cidade 
(Pimenta 2005). Em traços largos, na fase mais precoce da presença romana, verifica-se o domínio absoluto do consumo de vinho produzido na costa tirrénica da Península Itálica e transportado nas Greco-Itálicas e Dressel 1, seguido dos produtos piscícolas da costa meridional da Ulterior, em proporções algo mais baixas e principalmente envasados nas T-7.4.3.3. Em simultâneo, observa-se uma muito reduzida representatividade do azeite, que provém da costa adriática de Itália, nas ânforas de Brindisi, e do Norte de África, nas Africana Antiga. A chegada destes produtos inseria-se numa rede de abastecimento público ao exército (Fabião 1989; Pimenta 2005; Filipe 2015).

Uma das principais novidades introduzidas pela amostra do Pátio José Sequeira refere-se à documentação de uma asa de Dressel 4 de Cos, com marca com caracteres gregos, testemunhando a importação dos vinhos daquela ilha do Egeu para Olisipo. Esta evidência, a par da recente identificação de uma ânfora Ródia na Praça Nova, Castelo de São Jorge (Filipe 2019), vem complementar o panorama conhecido das importações republicanas, ampliando a diversidade de regiões de origem e aproximando ainda mais o repertório anfórico da cidade da foz do Tejo aos de outros locais, sobretudo da metade oriental da Hispânia, nomeadamente de Valentia (Ribera i Lacomba 2009; 2013). Enquadrado no aprovisionamento aos contingentes militares destacados no ocidente Peninsular, o comércio dos vinhos do Mediterrâneo oriental estaria associado ao dos vinhos itálicos, destinando-se muito provavelmente às patentes mais altas do exército romano ou às elites locais (Pérez Ballester 1994: 357; Pascual Berlanga - Ribera i Lacomba 2013: 261).

Será igualmente de realçar a aparente inconsistência dos dados entre estes dois conjuntos e os do Castelo de São Jorge (Pimenta 2005) no que se refere às proporções de Greco-Itálicas adriáticas e imitações sud-hispânicas desse tipo. A este propósito, é pertinente mencionar a premente carência de análises químicas e petrográficas a alguns grupos de fabrico das ânforas com origem extraprovincial documentadas em Lisboa, não só em relação aos contentores republicanos, mas também aos do Império e da Antiguidade Tardia.

Os dois conjuntos acrescentam dados igualmente interessantes ao panorama das importações enquadráveis no século I a.C. Sublinha-se a presença relativamente significativa das designadas Dressel $1 \mathrm{C}$ no Largo de Santa Cruz do Castelo, até agora pouco documentadas no Castelo de São Jorge. No mesmo sentido, constata-se a ocorrência das produções ovóides do Vale do Guadalquivir e da costa meridional da Ulterior, designadamente das Classe 67/Ovóide 1, Ovóide 4 e Ovóide 5, para além da Lusitana Antiga de produção local/regional, cujo exemplar reconhecido se poderá enquadrar na mesma centúria ou já no século I d.c.

Ainda que estatisticamente pouco representativas, a identificação de produções alto-imperiais nos dois locais reveste-se de particular interesse, tendo em conta a escassez de materiais dessa época na área da antiga Alcáçova. Marcam presença sobretudo formas vinárias, estando atestadas as Haltern 70 do Vale do Guadalquivir, as Dressel 2-4 da costa tirrénica de Itália, as Cretense 4/Dressel 43 da ilha de Creta e as Lusitana 3 de produção local/regional. $O$ quadro completa-se com o azeite da Baetica, transportado nas Dressel 20, neste caso da fase de Nero-Vespasiano.

Apesar do expressivo avolumar de dados a que se tem assistido nos últimos anos, existem ainda muitas questões por responder relativamente ao tipo de ocupações que a antiga Alcáçova Islâmica conheceu entre a República e a Antiguidade Tardia. Faltam sobretudo estruturas e contextos demonstrativos da funcionalidade dos espaços, mas falta também um maior investimento no estudo e publicação dos dados já colectados, nomeadamente em sítios com contextos tão importantes como o Pátio José Pedreira de que apenas se conhece o conjunto anfórico. 


\section{Referências bibliográficas}

ALMEIDA, R. R. de (2008) - Las Ánforas del Gualdalquivir en Scallabis (Santarém, Portugal). Aportación al Conocimiento de Los Tipos Minoritarios. (Instrumenta 28). Barcelona.

ALMEIDA, R. R. de - PIMENTA, J. (2018) - Ânforas do acampamento/ sítio romano de Alto dos Cacos (Almeirim, Portugal). Onoba. 6, 3-56.

ALMEIDA, R. - SÁNCHEZ HIDALGO, F. (2013) - Las ánforas del Cuartel de Hernán Cortés. Nuevos datos para el estudio de la importación y consumo en Augusta Emerita. In BERNAL CASASOLA, D. - JUAN TOVAR, L. C. - BUSTAMANTE ÁLVAREZ, M. - DÍAZ RODRÍGUEZ, J. J. - SÁEZ ROMERO, A. M., (eds.) Hornos, talleres y focos de producción alfarera en Hispania (I Congreso Internacional de la SECAH). Vol. II. Cádis, 49-58.

ARRUDA, A. M. - VIEGAS, C. - BARGÃO, P. (2005) - As ânforas da Bética costeira na Alcáçova de Santarém. Revista Portuguesa de Arqueologia. 8(1), 279-297.

BANHA, C. (2006) - As ânforas romanas de Idanha-a-Velha (Civitas Igaeditanorum). Dissertação de Mestrado em Pré-história e Arqueologia, apresentada à Faculdade de Letras da Universidade de Lisboa.

BARGÃO, P. (2006) - As importações anfóricas do Mediterrâneo durante a Época Romana Republicana na Alcáçova de Santarém. Dissertação de Mestrado em Pré-história e Arqueologia, apresentado à Faculdade de Letras da Universidade de Lisboa.

BENQUET, L. - GRIZEAUD, J.-J. (2009) - Découvertes récentes dans le quartier Saint-Roch à Toulouse (Haute-Garonne). In S.F.E.C.A.G. - Actes du Congrès de Colmar, Marselha, 655-670.

BENQUET, L. - OLMER, F. (2002) - Les amphores. In BLÁZQUEZ MARTÍNEZ, J. M. - DOMERGUE, C. - SILLIÈRES, P. (dirs.) La Loba (Fuenteobejuna, Cordoue, Espagne). La mine et le village minier antiques. Bordéus, 295-331.

BERNAL, D. - ARÉVALO, A. - LORENZO, L. - AGUILERA, L. (2003) - Imitations of Italic amphorae for fish sauce in Baetica. New evidence from the salt-fish factory of Baelo Claudia (Hispania). In Rei Cretariae Romanae Favtorvm Acta 38. Bona, 305-313.

BERNAL CASASOLA, D. - ROLDÁN GÓMEZ, L. - BLÁNQUEZ PEREZ, J. - SÁEZ ROMERO, A. M. (2011) - De la producción anfórica de Carteia en Época Republicana. Primeras evidencias. In ABELLÁN PÉREZ, J. - LAZARICH GONZÁLEZ, C. - CASTAÑEDA FERNÁNDEZ, V. (eds.) - Homenaje a Antonio Caro Bellido, Vol. Il. Cádiz, 65-82.

BERNI MILLET, P. (2008) - Epigrafía anfórica de la Bética. Nuevas formas de análisis. (Instrumenta 29). Barcelona.

BERNI MILLET, P. (2011) - Tipologia de la Haltern 70. In CARRERAS MONFORT, C. - MORAIS, R. - GONZÁLEZ FERNÁNDEZ, E. (coords.) - Ánforas romanas de Lugo, Comercio romano en el Finis terrae (Traballos de Arqueoloxía 3). Lugo, 80-107.

BERNI MILLET, P. (2017) - Amphorae-epigraphy: stamps, graffiti and tituli picti from roman Nijmegen. Sellos. In CARRERAS MONFORT, C. - BERG, J. van der (eds.) - Amphorae from the Kops Plateau (Nijmegen): trade and supply to the lower-rhineland from the Augustan period to AD 69/70 (Roman Archaeology 20). Oxford, 189-282.

BEZECZKY, T. (2013) - The Amphorae of Roman Ephesus. (Forschungen in Ephesos, 15, 1). Viena.

CAPELLI, C. - CONTINO, A. (2013) - Amphores tripolitaines ou africaines anciennes? Antiquités Africaines. 49, 199-208.

CARDOSO, J. P. (2013) - Ânforas romanas recuperadas em meio subaquático em Portugal. Lisboa.
CARRERAS MONFORT, C. - MARTÍN MENÉNDEZ, A. - PERA ISERN, J. - RODRIGO REQUENA, E. (2016) - Las ánforas de Brindisi en la Hispania Citerior. Pautas de distribución y consumo. Sagvntvm. 48, $103-121$.

DESY, P. (1989) - Les timbres amphoriques de l'Apulie républicaine. Documents pour une histoire économique et sociale. (B.A.R. International Series 554). Oxford.

DIOGO, A. M. D. (1987) - Quadro tipológico das ânforas de fabrico lusitano. O Arqueólogo Português. S. IV(5), 179-191.

DIOGO, A. M. D. - ALVES, F. J. S. (1988-1989) - Ânforas provenientes do meio fluvial nas imediações de Vila Franca de Xira e de Alcácer do Sal. O Arqueólogo Português. S.IV(6-7), 227-240.

EMPEREUR, J. Y. - HESNARD, A. (1987) - Les amphores hellénistiques. In LÉVÊQUE, P. - MOREL, J.-P. (eds.) - Cerámiques Hellénistiques et Romaines II (Centre de Recherches d'Histoire Ancienne, 70). Paris, 9-71.

FABIÃO, C. (1987) - Ânforas romanas republicanas de um depósito de Mértola, no Museu Nacional de Arqueologia e Etnologia. O Arqueólogo Português. S.IV(5), 125-148.

FABIÃO, C. (1989) - Sobre as ânforas do acampamento romano da Lomba do Canho (Arganil) (Cadernos da UNIARQ 1). Lisboa.

FABIÃO, C. (1998) - O vinho na Lusitânia: reflexões em torno de um problema arqueológico. Revista Portuguesa de Arqueologia. $1(1), 169-198$.

FABIÃO, C. (2001) - Sobre as mais antigas ânforas «romanas» da Baetica no ocidente Peninsular. In Actas del Congreso Internacional Ex Baetica Amphorae. Conservas y vino de la Bética en el Imperio Romano, Vol. 2. Écija, 665-682.

FABIÃO, C. - GUERRA, A. - ALMEIDA, J. - ALMEIDA, R. - PIMENTA, J. - FILIPE, V. (2016) - Marcas de ânforas romanas na Lusitânia (do Museu Nacional de Arqueologia de Lisboa ao Museo Nacional de Arte Romano de Mérida). (Corpus Internationale des Timbres Amphoriques, Fascicule 19). Lisboa.

FILIPE, V. (2010) - As ânforas de tradição pré-romana de Mesas do Castelinho. Revista Portuguesa de Arqueologia. 13(1), 57-87.

FILIPE, V. (2015) - As ânforas do teatro romano de Olisipo (Lisboa, Portugal): campanhas 2001-2006. Spal. 24, 129-163.

FILIPE, V. (2018) - Consumption patterns on the edge of the Roman Empire: the import of amphorae in Olisipo (Lisbon, Portugal) between the 2 nd century BC and the 2 nd century AD. In Rei Cretariae Romanae Favtorvm Acta 45. Bona, 91-97.

FILIPE, V. (2019) - Olisipo, o grande porto romano da fachada atlântica. Economia e comércio entre a República e o principado. Tese de Doutoramento em História, na especialidade de Arqueologia, apresentada à Faculdade de Letras da Universidade de Lisboa.

FILIPE, V. (2020) - Las producciones anfóricas romanas más antiguas del occidente de la Península Ibérica en Olisipo (Lisboa): contribución a su estudio. Spal. 29(2), 179-204.

FILIPE, V. (2021) - Las ánforas vinarias Alto-Imperiales de Lusitania: estado de la questión. Lucentum. 40, 197-214.

FILIPE, V. - CALADO, M. - FIGUEIREDO, M. - CASTRO, A. (2013) - Intervenção arqueológica na Rua do Espírito Santo, Castelo (Lisboa): do Romano Republicano à Época Contemporânea. Dados preliminares. Al-Madan, Adenda electrónica. II:17, 6-12.

FRASER, P. M. - MATTHEWS, E. (1987) - A lexicon of Greek personal names I. The Aegean islands, Cyprus, Cyrenaica. Oxford. 
GARCÍA FERNÁNDEZ, F. J. - PALMA, M. F. - GARCÍA VARGAS, E. - SÁEZ ROMERO, A. - FILIPE, V. - ALBUQUERQUE, P. (2020) Mértola entre la Edad del Hierro y la Romanización: nuevos datos a partir de las excavaciones de la Biblioteca Municipal. Arqueologia Medieval. 15, 5-24.

GARCÍA VARGAS, E. (1998) - La producción de ánforas en la bahía de Cádiz en Época Romana (siglos II A.C. - IV D.C.). Écija.

GARCÍA VARGAS, E. - ALMEIDA, R. - GONZÁLEZ CESTEROS, H. (2011) - Los tipos anfóricos del Guadalquivir en el marco de los envases hispanos del siglo I a.C. Un universo heterogéneo entre la imitación y la estandarización. Spal. 20, 185-283.

GARCÍA VARGAS, E. - ALMEIDA, R. - GONZÁLEZ CESTEROS, H. (2016) - Ovoid 5 (Guadalquivir Valley). In Amphorae ex Hispania. Landscapes of production and consumption Disponível em http://amphorae.icac.cat/amphora/ovoid-5-guadalquivir-valley). Consultado a 02-05-2021.

GARCÍA VARGAS, E. - BERNAL CASASOLA, D. - DIAZ RODRIGUEZ, J. - SÁEZ ROMERO, A. M. (2016) - Dressel 1 (Baetica Ulterior coast). In Amphorae ex Hispania. Landscapes of production and consumption. Disponível em http://amphorae.icac.cat/ amphora/dressel-1-baetica-ulterior-coast. Consultado a 24-04-2021.

GOMES, A. - GASPAR, A. (2017) - Pavimentos da Idade do Ferro no Castelo de São Jorge. In FERNANDES, L. - BUGALHÃO, J. - FERNANDES, P. A. (coords.) - Debaixo dos nossos pés. Pavimentos históricos de Lisboa. Lisboa, 90-91.

GONZÁLEZ CESTEROS, H. - ALMEIDA, R. - GARCÍA VARGAS, E. (2016) - Ovoid 1 (Guadalquivir Valley). In Amphorae ex Hispania. Landscapes of production and consumption. Disponível em http://amphorae.icac.cat/amphora/ovoid-1-guadalquivir-valley. Consultado a 07-05-2021.

GUERRA, S. (2017) - Largo de Santa Cruz do Castelo: um exemplo de revestimento em argila. In FERNANDES, L. - BUGALHÃO, J. - FERNANDES, P. A. (coords.) - Debaixo dos nossos pés. Pavimentos históricos de Lisboa. Lisboa, 88-89.

HERAS MORA, F. J. - BUSTAMANTE ÁLVAREZ, M. (2007) Contribución al estudio de las ánforas tardorrepublicanas del enclave militar de "El Santo" de Valdetorres (Badajoz, España). Vipasca. Arqueologia e História. 2(2), 318-324.

JOAQUINITO, A. (2017) - Estruturas pré-Pombalinas e espólio associado no Pátio José Pedreira (Rua do Recolhimento e Beco do Leão, freguesia Santa Maria Maior). In ARNAUD, J. M. - MARTINS, A. (eds.) - Arqueologia em Portugal. 2017: estado da questão. Lisboa, 1767-1779.

LAGÓSTENA BARRIOS, L. - BERNAL CASASOLA, D. (2004) - Alfares y producciones cerámicas en la provincia de Cádiz. Balance y perspectivas. In BERNAL CASASOLA, D. - LAGÓSTENA BARRIOS, L. (eds.) - Figlinae Baeticae. Talleres alfareros y producciones cerámicas en la Bética romana (ss. Il a.C.-IV d.C.) (B.A.R. International Series 1266). Oxford, 39-124.

MANACORDA, D. (1989) - Le anfore dell'Italia repubblicana: aspetti economici e sociali. In Amphores romaines et histoire économique. In Dix ans de recherche. Actes du colloque de Sienne (22-24 mai 1986) (Publications de l'École française de Rome 114). Roma:, 443-467.

MARANGOU-LERAT, A. (1995) - Le vin et les amphores de Crète de l'époque classique à l'époque impériale. (Études crétoises, 30). Atenas.

MÁRQUEZ VILLORA, J. C. - MOLINA VIDAL, J. (2005) - Del Hiberus a Carthago Nova. Comercio de alimentos y epigrafía anfórica grecolatina. (Instrumenta 18). Barcelona.
MATEO CORREDOR, D. (2016) - Comercio anfórico y relaciones mercantiles en Hispania Ulterior (ss. II a. C. - II d. C.). (Instrumenta 52). Barcelona.

MOLINA VIDAL, J. (1997) - La dinámica comercial romana entre Italia e Hispania Citerior. Alicante.

MORAIS, R. (2004) - Bracara Augusta: um pequeno "testaccio" de ânforas Haltern 70. Considerações e problemáticas de estudo. In BERNAL, D. - LAGÓSTENA, L. (eds.) - Figlinae Baeticae. Talleres alfareros y producciones cerámicas en la Bética romana (ss. Il a.C.-IV d.C.) (B.A.R. International Series 1266). Oxford, 545-565.

MORAIS, R. - OLIVEIRA, C. - ARAÚJO, A. (2016) - Lusitanian Amphorae of the Augustan Era and their Contents: Organic Residue Analysis. In PINTO, I. V. - ALMEIDA, R. - MARTIN, A. (eds.) - Lusitanian Amphorae: Production and Distribution (Roman and Late Antique Mediterranean Pottery 10). Oxford, 105-109.

MOTA, N. - PIMENTA, J. - SILVA, R. B. (2014) - Acerca da ocupação romana republicana de Olisipo: os dados da intervenção na Rua do Recolhimento n. ${ }^{\circ}$ 68-70. In FABIÃO, C. - PIMENTA, J. (coords.) - Actas do Congresso Conquista e Romanização do Vale do Tejo (Cira Arqueologia 3). Vila Franca de Xira, 149-177.

OLCESE, G. (2011-2012) - Atlante dei siti di produzione ceramica (Toscana, Lazio, Campania e Sicília) con le tabelle dei principali relitti del Mediterraneo Occidentale (IV secolo a.C.-I secolo d.C.). (Immensa Aequora 2). Roma.

OLIVEIRA, C. - MORAIS, R. - ARAÚJO, A. (2015) - Application of gas cromatography coupled with mass spectrometry to the analysis of ceramic containers of Roman Period. Evidence from the peninsular northwest. In OLIVEIRA, C. - MORAIS, R. MORILLO CERDÁN, A. (eds.) - ArchaeoAnalytics. Chromatography and DNA analysis in archaeology. Esposende, 193-212.

OPAIT, A. (2010) - Aspects of the provisioning of the Pontic settlements with olive oil in the Hellenistic and Early Roman period. In TEZGÖR, D. - INAISHVILI, N. (eds.) - PATABS I. Production and trade of amphorae in the Black Sea. Istambul, 153-158.

PALAZZO, P. (2013) - Le anfore di Apani (Brindisi). Roma.

PASCUAL BERLANGA, G. - RIBERA i LACOMBA, A. (2002) Las ánforas tripolitanas antiguas en el contexto del Occidente Mediterráneo. Un contenedor poco conocido de la Época Republicana. In RIVET, L. - SCIALLANO, M. (eds.) - Vivre, produire et échanger: reflets méditerranéens. Mélanges offerts à Bernard Liou. Montagnac, 303-318.

PASCUAL BERLANGA, G. - PÉREZ BALLESTER, J. (2017) - El comercio de vino griego en la península Ibérica (siglos III a.C.-I d.C.). In AQUILUÉ ABADÍAS, X. - CABRERA BONET, P. ORFILA PONS, M. (eds.) - Homenaje a Glòria Trias Rubiés. Cerámicas griegas de la Península lbérica: cincuenta años después (1967-2017). Barcelona, 294-307.

PASCUAL BERLANGA, G. - RIBERA i LACOMBA, A. (2013) El material más apreciado por los antiguos. Las ánforas. In RIBERA i LACOMBA, A. (ed.) - Manual de cerámica romana. Del mundo Helenístico al Imperio Romano. Madrid, 215-289.

PEACOCK, D. P. S. - WILLIAMS, D. F. (1986) - Amphorae and the Roman Economy, an Introductory Guide. Londres.

PÉREZ BALLESTER, J. (1994) - Asociaciones de laginos, boles helenísticos de relieves y ánforas rodias en contextos mediterráneos (siglos II y I a.C.). In CABRERA BONET, P. OLMOS ROMERA, R. - SANMARTÍ i GREGO, E. (coords.) - Iberos y Griegos: lecturas desde la diversidad (Huelva Arqueologica XIII:2). Huelva, 346-365. 
PIMENTA, J. (2005) - As ânforas romanas do Castelo de São Jorge (Lisboa). (Trabalhos de Arqueologia 41). Lisboa.

PIMENTA, J. (2007) - A importação de ânforas de preparados piscícolas em Olisipo (séculos II-I a.C.). In LAGÓSTENA BARRIOS, L. - BERNAL CASASOLA, D. - ARÉVALO GONZÁLEZ, A. (eds.) - CETARIAE. Salsas y salazones de pescado en Occidente durante la Antigüedad (B.A.R. International Series 1686). Oxford, 221-233.

PIMENTA, J. (2014) - Os contextos da conquista: Olisipo e Decimo Juno Bruto. In FABIÃO, C. - PIMENTA, J. (coords.) - Actas do Congresso Conquista e Romanização do Vale do Tejo (Cira Arqueologia 3). Vila Franca de Xira, 44-60.

PIMENTA, J. - CALADO, M. - LEITÃO, M. (2005) - Novos dados sobre a ocupação pré-romana da cidade de Lisboa: as ânforas da sondagem n. ${ }^{\circ} 2$ da Rua de São João da Praça. Revista Portuguesa de Arqueologia. 8(2), 313-334.

PIMENTA, J. - GASPAR, A. - GOMES, A. - MOTA, N. - MIRANDA, P. (2014) - O estabelecimento romano republicano de Olisipo: estrutura e contextos do Beco do Forno do Castelo, Lote 40 (n. ${ }^{\circ}$ 16-20) - Lisboa. In FABIÃO, C. - PIMENTA, J. (coords.) - Actas do Congresso Conquista e Romanização do Vale do Tejo (Cira Arqueologia 3). Vila Franca de Xira, $122-148$

PIMENTA, J. - MENDES, H. (2014) - Monte dos Castelinhos: Vila Franca de Xira. Um sítio singular para o estudo da romanização do Vale do Tejo. In MAYORAL HERRERA, V. - MATALOTO, R. - ROQUE, C. (eds.) - La gestación de los paisajes rurales entre la Prehistoria y el período romano. Formas de asentamiento y procesos de implantación (Anejos de Archivo Español de Arqueología 70). Mérida, 125-142.

PIMENTA, J. - RIBERA i LACOMBA, A. - SORIA, V. (2014) Le ceramiche a vernice nera italica dei livelli di fondazione di Olisipo e Valentia (140-130 a.C.). In Rei Cretariae Romanae Favtorvm Acta 45. Bona, 115-125.

QUARESMA, J. C. - RAPOSO, J. (2016) - Lusitana 3 (Western Lusitania). Amphorae ex Hispania. Landscapes of production and consumption. Disponível em http://amphorae.icac.cat/ amphora/lusitana-3-western-lusitania. Consultado a 05-05-2021.

RAMON TORRES, J. (1995) - Las ánforas fenicio-púnicas del Mediterráneo central y occidental. (Instrumenta 2). Barcelona.

REMESAL RODRÍGUEZ, J. (1986) - La annona militaris y la exportación de aceite bético a Germania. Madrid.

RIBERA i LACOMBA, A. (2009) - La fundación de Valentia: un apendice de Italia y Campania en la Hispania del siglo II a.C. OEBALUS, Studi sulla Campania nell'Antichità. 4, 41-77.
RIBERA i LACOMBA, A. (2013) - Los pecios del litoral ibérico y la fundación (138 a.C.) y destrucción de Valentia (75 a.C.). In OLCESE, G. (ed.) - Immensa Aequora 3: Ricerche archeologiche, archeometriche e informatiche per la ricostruzione dell'economia e dei commerci nel bacino occidentale del Mediterraneo (metà IV sec. a.C. - I sec. d.C.). Roma, 455-468.

RIZZO, G. (2014) - Le anfore, Ostia e i commerci mediterranei. In PANELLA, C. - RIZZO, G. (eds.) - Ostia VI. Le Terme del Nuotatore. Roma, 65-440.

SÁEZ ROMERO, A. M. (2008) - La producción cerámica en Gadir en época tardopúnica (siglos -III/-I). (B.A.R. International Series 1812). Oxford.

SÁEZ ROMERO A. M. (2016) - Ramon T-9111 (Baetica Ulterior coast). In Amphorae ex Hispania. Landscapes of production and consumption. Disponível em http://amphorae.icac.cat/amphora/ ramon-t-9111-baetica-ulterior-coast. Consultado em 29-04-2021.

SILVA, R. B. (2012) - As "marcas de oleiro" na terra sigillata e a circulação dos vasos na Península de Lisboa. Dissertação de Doutoramento, Faculdade de Ciências Sociais e Humanas, Universidade Nova de Lisboa.

SOUSA, E. (2014) - A ocupação pré-romana da foz do Estuário do Tejo. (Estudos e Memórias 7). Lisboa.

SOUSA, E. - GUERRA, S. (2018) - A presença fenícia em Lisboa: novos vestígios descobertos no alto da colina do Castelo de São Jorge. Sagvntvm. 50, 57-88.

SOUSA, E. - PIMENTA, J. (2014) - A produção de ânforas no Estuário do Tejo durante a Idade do Ferro. In MORAIS, R. FERNÁNDEZ FERNÁNDEZ, A. - SOUSA, M. J. (eds.) As produções cerâmicas de imitação na Hispania. Vol. I (Col. Monografias Ex Officina Hispana 2.). Porto, 303-316.

SOUSA, E. - PINTO, M. (2016) - A ocupação da Idade do Ferro na colina do Castelo de São Jorge (Lisboa, Portugal): novos dados das escavações realizadas na Rua do Recolhimento/Beco do Leão. Apontamentos de Arqueologia e Património. 11, 59-67.

TCHERNIA, A. (1986) - Le vin de l'Italie romaine. Essai d'histoire économique d'après les amphores. Paris.

TORRES COSTA, J. - MARLIÈRE, E. - NICOLÁS MASCARÓ, J. C. de (2014) - Minucias epigráficas pintadas sobre ánforas grecoitálicas de Ibiza y Menorca. In Miscel.lània d'estudis en homenatge a Jordi H. Fernández. Ibiza, 615-626.

VIEGAS, C. (2011) - A ocupação romana do Algarve: estudo do povoamento e economia do Algarve central e oriental no período romano. (Estudos \& Memórias 3). Lisboa.

WILL, E. L. (1983) - Exportation of Olive Oil from Baetica to the Eastern Mediterranean. In BLÁZQUEZ MARTÍNEZ, J. M. REMESAL RODRÍGUEZ, J. (eds.) - Producción y Comercio del aceite en la Antigüedad. Segundo Congreso Internacional. Madrid, 391-440. 


\section{POLÍTICA EDITORIAL}

A Ophiussa - Revista do Centro de Arqueologia da Universidade de Lisboa foi iniciada sob a direcção de Victor S. Gonçalves em 1996, tendo sido editado o volume 0. O volume 1 (2017) é uma edição impressa e digital da UNIARQ - Centro de Arqueologia da Universidade de Lisboa.

O principal objectivo desta revista é a publicação e divulgação de trabalhos com manifesto interesse, qualidade e rigor científico sobre temas de Pré-História e Arqueologia, sobretudo do território europeu e da bacia do Mediterrâneo.

A Ophiussa - Revista do Centro de Arqueologia da Universidade de Lisboa publicará um volume anual. A partir de 2018, os artigos submetidos serão sujeitos a um processo de avaliação por parte de revisores externos (peer review). O período de submissão de trabalhos decorrerá sempre no primeiro trimestre e a edição ocorrerá no último trimestre de cada ano.

A revista divide-se em duas secções: artigos científicos e recensões bibliográficas. Excepcionalmente poderão ser aceites textos de carácter introdutório, no âmbito de homenagens ou divulgações específicas, que não serão submetidos à avaliação por pares. Isentas desta avaliação estão também as recensões bibliográficas.

Todas as submissões serão avaliadas, em primeira instância, pela Coordenação Editorial, no que respeita ao seu conteúdo formal e à sua adequação face à política editorial e às normas de edição da revista. Os trabalhos que cumprirem estes requisitos serão posteriormente submetidos a um processo de avaliação por pares cega / blind peer review (mínimo de dois revisores). O Conselho Científico, constituído pela direcção da UNIARQ e por investigadores externos, acompanhará o processo de edição.

Esta etapa será concretizada por investigadores externos qualificados, sendo os respectivos pareceres entregues num período não superior a três meses. Os revisores procederão à avaliação de forma objectiva, tendo em vista a qualidade do conteúdo da revista; as suas críticas, sugestões e comentários serão, na medida do possível, construtivos, respeitando as capacidades intelectuais do(s) autor(es). Após a recepção dos pareceres, o(s) autor(es) tem um prazo máximo de um mês para proceder às alterações oportunas e reenviar o trabalho.

A aceitação ou recusa de artigos terá como únicos factores de ponderação a sua originalidade e qualidade científica. O processo de revisão é confidencial, estando assegurado o anonimato dos avaliadores e dos autores dos trabalhos, neste último caso até à data da sua publicação.

Os trabalhos só serão aceites para publicação a partir do momento em que se conclua o processo da revisão por pares. Os textos que não forem aceites serão devolvidos aos seus autores. O conteúdo dos trabalhos é da inteira respon- sabilidade do(s) autor(es) e não expressa a posição ou opinião do Conselho Científico ou da Coordenação Editorial. A Revista Ophiussa segue as orientações estabelecidas pelo Commitee on Publication Ethics (COPE, Comité de Ética em Publicações): https://publicationethics.org/.

O processo editorial decorrerá de forma objectiva, imparcial e anónima. Erros ou problemas detetados após a publicação serão investigados e, se comprovados, haverá lugar à publicação de correções, retratações e/ou respostas. As colaborações submetidas para publicação devem ser inéditas. As propostas de artigo não podem incluir qualquer problema de falsificação ou de plágio. Para efeito de detecção de plágio será utilizada a plataforma URKUNDU (https:// www.urkund.com/pt-br/).

As ilustrações que não sejam do(s) autor(es) devem indicar a sua procedência. O Conselho Científico e a Coordenação Editorial assumem que os autores solicitaram e receberam autorização para a reprodução dessas ilustrações, e, como tal, rejeitam a responsabilidade do uso não autorizado das ilustrações e das consequências legais por infracção de direitos de propriedade intelectual.

É assumido que todos os Autores fizeram uma contribuição relevante para a pesquisa reportada e concordam com o manuscrito submetido. Os Autores devem declarar de forma clara eventuais conflitos de interesse. As colaborações submetidas que, direta ou indiretamente, tiveram o apoio económico de terceiros, devem claramente declarar essas fontes de financiamento.

Os textos propostos para publicação devem ser inéditos e não deverão ter sido submetidos a qualquer outra revista ou edição electrónica. Aceitam-se trabalhos redigidos em português, inglês, espanhol, italiano e francês.

Esta edição disponibiliza de imediato e gratuitamente a totalidade dos seus conteúdos, em acesso aberto, de forma a promover, globalmente, a circulação e intercâmbio dos resultados da investigação científica e do conhecimento.

A publicação de textos na Ophiussa - Revista do Centro de Arqueologia da Universidade de Lisboa não implica o pagamento de qualquer taxa nem dá direito a qualquer remuneração económica.

Esta publicação dispõe de uma versão impressa, a preto e branco, com uma tiragem limitada, que será distribuída gratuitamente pelas bibliotecas e instituições mais relevantes internacionalmente, e intercambiada com publicações periódicas da mesma especialidade, que serão integradas na Biblioteca da Faculdade de Letras da Universidade de Lisboa. Conta, paralelamente, com uma versão digital, a cores, disponibilizada no endereço www.ophiussa.letras.ulisboa.pt, onde se pode consultar a totalidade da edição.

Para mais informações: ophiussa@letras.ulisboa.pt 


\section{EDITORIAL POLICY}

Ophiussa - Revista do Centro de Arqueologia da Universidade de Lisboa started in 1996, with the edition of volume 0 . From 2017, this journal is a printed and digital edition of UNIARQ - Centro de Arqueologia da Universidade de Lisboa.

The main objective of this journal is the publication and dissemination of papers of interest, quality and scientific rigor concerning Prehistory and Archeology, mostly from Europe and the Mediterranean basin.

Ophiussa - Revista do Centro de Arqueologia da Universidade de Lisboa will publish an annual volume. From 2018, submitted articles will be subject to a peer-review evaluation process. The submission period will always occur in the first quarter of each year and the edition will occur in the last quarter.

The journal is divided into two sections: scientific articles and bibliographic reviews. Exceptionally, texts of an introductory nature may be accepted, in the context of specific tributes or divulgations, which will not be submitted to peer-review evaluation. Exemptions from this evaluation are also the bibliographic reviews.

All submissions will be considered, in the first instance, by the Editorial Board, regarding its formal content and adequacy in face of the editorial policy and the journal's editing standards. Papers that meet these requirements will subsequently be submitted to a blind peerreview process (minimum of two reviewers). The Scientific Council, constituted by the directors of UNIARQ and external researchers, will follow the editing process.

This stage will be carried out by qualified external researchers, and their feedback will be delivered within a period of no more than two months. The reviewers will carry out the evaluation in an objective manner, in view of the quality and content of the journal; their criticisms, suggestions and comments will be, as far as possible, constructive, respecting the intellectual abilities of the author(s). After receiving the feedback, the author(s) has a maximum period of one month to make the necessary changes and resubmit the work.

Acceptance or refusal of articles will have as sole factors of consideration their originality and scientific quality. The review process is confidential, with the anonymity of the evaluators and authors of the works being ensured, in the latter case up to the date of its publication.

Papers will only be accepted for publication as soon as the peer review process is completed. Texts that are not accepted will be returned to their authors. The content of the works is entirely the responsibility of the author(s) and does not express the position or opinion of the Scientific Council or Editorial Board. The Journal Ophiussa follows the guidelines established by the Commitee on Publication Ethics (COPE, the Ethics Committee Publications): https:// publicationethics.org/
The editorial process will be conducted objectively, impartially and anonymously. Errors or problems detected after publication will be investigated and, if proven, corrections, retractions and / or responses will be published. Contributions submitted for publication must be unpublished. Article submissions can not include any problem of forgery or plagiarism. In order to detect plagiarism, the URKUNDU platform will be used.

Illustrations that are not from the author(s) must indicate their origin. The Scientific Council and Editorial Board assume that the authors have requested and received permission to reproduce these illustrations and, as such, reject the responsibility for the unauthorized use of the illustrations and legal consequences for infringement of intellectual property rights.

It is assumed that all Authors have made a relevant contribution to the reported research and agree with the manuscript submitted. Authors must clearly state any conflicts of interest. Collaborations submitted that directly or indirectly had the financial support of third parties must clearly state these sources of funding.

Texts proposed for publication must be unpublished and should not have been submitted to any other journal or electronic edition. Works written in Portuguese, English, Spanish, Italian and French are accepted.

The publication of texts in Ophiussa - Revista do Centro de Arqueologia da Universidade de Lisboa does not imply the payment of any fee nor does it entitle to any economic remuneration.

This edition immediately and freely provides all of its content, in open access, in order to promote global circulation and exchange of scientific research and knowledge. This publication has a limited printed edition in black and white, which will be distributed free of charge by the most relevant international libraries and institutions, and exchanged with periodicals of the same specialty, which will be integrated in the Library of Faculdade de Letras of Universidade de Lisboa. It also has a digital version, in color, available at address http://ophiussa.letras.ulisboa.pt, where one can consult the entire edition.

For more information contact: ophiussa@letras.ulisboa.pt 
REVISTA DO CENTRO DE ARQUEOLOGIA DA UNIVERSIDADE DE LISBOA

ÍNDICE

O tecno-complexo Acheulense em Portugal:

contribuição para um balanço dos conhecimentos

CARLOS FERREIRA, JOÃO PEDRO CUNHA-RIBEIRO, EDUARDO MÉNDEZ-QUINTAS

Brief overview of zooarchaeological research within the framework

of Middle Palaeolithic subsistence theories

MARIANA NABAIS

A distribuição espacial dos materiais líticos da UE003 do Rodo:

testemunho de reocupações do sítio ao longo do Tardiglaciar?

CRISTINA GAMEIRO, THIERRY AUBRY, BÁRBARA COSTA, SÉRGIO GOMES,

YANN LE JEUNE, CARMEN MANZANO, MAURIZIO ZAMBALDI

O sítio do Neolítico Antigo de Montum de Baixo (Melides - Alentejo Litoral)

63

JOAQUINA SOARES, CARLOS TAVARES DA SILVA, SUSANA DUARTE

A economia alimentar em Chibanes (Setúbal) - horizonte campaniforme

JOÃO LUÍS CARDOSO, CARLOS TAVARES DA SILVA, JOAQUINA SOARES, FILIPE MARTINS

Luto en la cara: ablaciones de duelo en el Mediterráneo Ancestral

ÁLVARO GÓMEZ PEÑA, JOSÉ LUIS ESCACENA CARRASCO

Dois conjuntos anfóricos do Castelo de São Jorge (Lisboa):

Largo de Santa Cruz do Castelo e Pátio José Pedreira

VICTOR FILIPE

A face romana de Santa Olaia (Figueira da Foz, Portugal) -

uma leitura possível a partir da cultura material

RICARDO COSTEIRA DA SILVA, SARA OLIVEIRA ALMEIDA, ISABEL PEREIRA

Cerâmica estampada britânica em Portugal (1780-1920).

Identidade, domesticidade e relações

TÂNIA CASIMIRO, INÊS CASTRO, TIAGO SILVA

Recensões bibliográficas

(TEXTOS: JOÃO LUÍS CARDOSO, ANA CATARINA SOUSA, VICTOR S. GONÇALVES,

FRANCISCO B. GOMES, PEDRO ALBUQUERQUE, LEYRE MORGADO-RONCAL)

Política editorial 